\title{
The Climate Change Alliance: botanic garden horticulturists as agents for change
}

\section{Peter Symes ${ }^{1} \&$ Clare Hart $^{2}$}

\begin{abstract}
In 2016, the publication of the pioneering Landscape Succession Strategy heralded a horticultural response by Royal Botanic Gardens Victoria to climate change risks faced by their living collections. This initiative led to the botanical world's first Climate Change Summit in 2018 and the subsequent establishment of the Climate Change Alliance of Botanic Gardens. This article describes some of the anticipated climatic changes facing the Melbourne Gardens site, the strategic management of collections when considering these challenges, and how other botanical organisations can benefit from this approach through collaboration and sharing of expertise.
\end{abstract}

\section{Melbourne Gardens, Royal Botanic Gardens Victoria}

Royal Botanic Gardens Victoria (RBGV) was established in 1846 on the banks of the Yarra River in Melbourne, Victoria (Australia). Today, the organisation encompasses two diverse sites: the original Gardens in Melbourne and the Cranbourne Gardens, first established as a division of RBGV in 1970 and open to the public since 1989. Melbourne Gardens are also home to the State Botanical Collection, held at the National Herbarium of Victoria, comprising the largest herbarium collection in Oceania (Thiers, 2021). RBGV is managed by the Royal Botanic Gardens Board Victoria, which is responsible to the Minister for Environment and Climate Change.

The Melbourne Gardens site covers 38.6 ha and is located about $2.4 \mathrm{~km}$ from the centre of the city of Melbourne. Melbourne Gardens can be portrayed as a 'Garden of the World', with the most recent analysis (RBGV, 2021b) confirming that 189 countries ( 98 per cent of recognised sovereign states) are represented in its living collection of over 7,500 taxa. The high plant diversity of the collections and landscape at Melbourne Gardens provides significant benefits to human wellbeing (Fuller et al., 2007; Shanahan et al., 2015) and, in common with many other botanic gardens, enables abundant learning and storytelling for visitors (Westwood et al., 2021).

Acknowledging that all accessioned specimens contribute to the Melbourne Gardens' living collection, there are over twenty actively curated collections grouped under five themes: Geographical; Ecological; Taxonomic and Evolutionary; Research and Conservation; and Ornamental and Cultural (Fig. 1). Each collection is overseen by a curator who develops and maintains these collections according to a Living Collections Strategy and collection-specific management plans.

\footnotetext{
${ }^{1}$ Peter Symes is Curator of Horticulture, Royal Botanic Gardens Victoria, Melbourne Gardens. Address: Private Bag 2000, South Yarra, 3141, Victoria, Australia.

Email: peter.symes@rbg.vic.gov.au

${ }^{2}$ Clare Hart is Manager Horticulture, Royal Botanic Gardens Victoria, Melbourne Gardens.

Address: as above.
} 


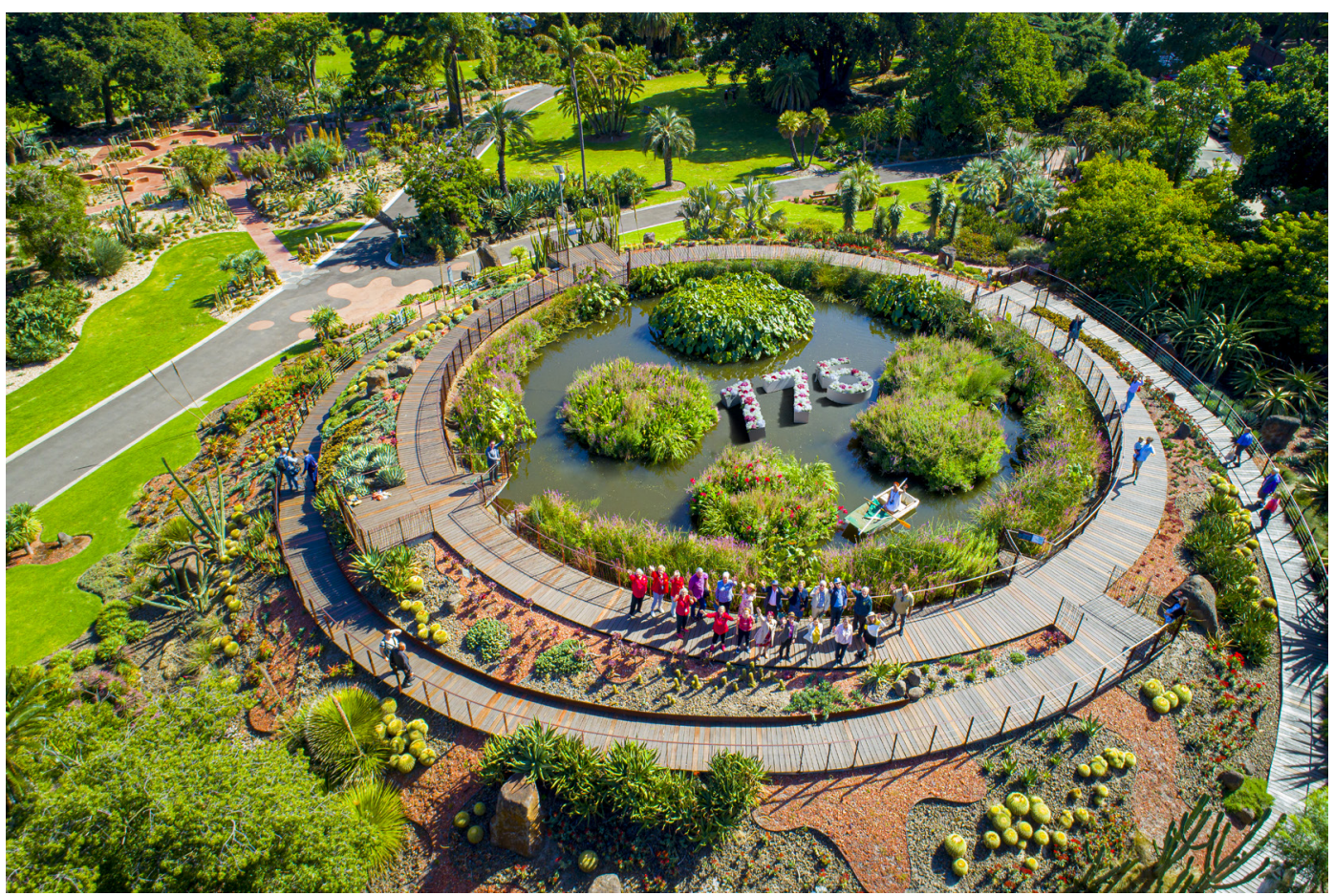

Fig. 1 Guilfoyle's Volcano (Ornamental and Cultural collection), as captured by drone during the 175th anniversary celebrations held for Melbourne Gardens. The Arid Garden, which can be seen towards the top left, forms part of the Cacti and Succulent (Taxonomic and Evolutionary) collection. Photo: A. Vittorio.

\section{Risks to the living collections at Melbourne Gardens}

\section{Climatic change: past}

Melbourne's historic mean annual

temperature from 1856 to 1950 was $14.7^{\circ} \mathrm{C}$.

However, the mean annual temperature

in the last 30 years has been about $16.2^{\circ} \mathrm{C}$

(Australian Bureau of Meteorology, 2021b).

Actual temperature change attributed to

global warming since 1910 is about $1{ }^{\circ} \mathrm{C}$

(Grose et al., 2015; Clarke et al., 2019). Some of this additional temperature rise could also be due to the growth of the city of Melbourne, resulting in increased urban thermal mass and urban heat island (UHI) effects (Akbari et al., 2016). Mean annual precipitation for Melbourne has sat at about $645 \mathrm{~mm}$ for most recorded years, but for the last 30 years that figure has fallen to an average of $592 \mathrm{~mm}$ and appears to be on a downward trend
(Australian Bureau of Meteorology, 2021b). In effect, the 'climatic envelope' (Fig. 2) in which Melbourne Gardens were established is already history and substantial change is projected to continue.

\section{Climatic change: future}

Under the current climate change scenarios of RCP4.5 and RCP8.5, ${ }^{3}$ by 2090 Melbourne could see the mean annual temperature rise by median values of $1.95^{\circ} \mathrm{C}$ to $3.45^{\circ} \mathrm{C}$

\footnotetext{
${ }^{3} \mathrm{RCP} 4.5$ and RCP8.5 are Representative Concentration Pathways, from Global Climate Models, representing 'intermediate' and 'business as usual' emissions scenarios respectively. These RCP scenarios were published by the Intergovernmental Panel on Climate Change (IPCC) Fifth Assessment Report (AR5). The IPCC is now in its sixth assessment cycle to produce the Sixth Assessment Report (AR6) in 2022. This report is likely to apply new Share Socioeconomic Pathways (SSPs) scenarios based on the sixth phase of the Coupled Model Intercomparison Project (CMIP6) (Grose et al., 2020).
} 


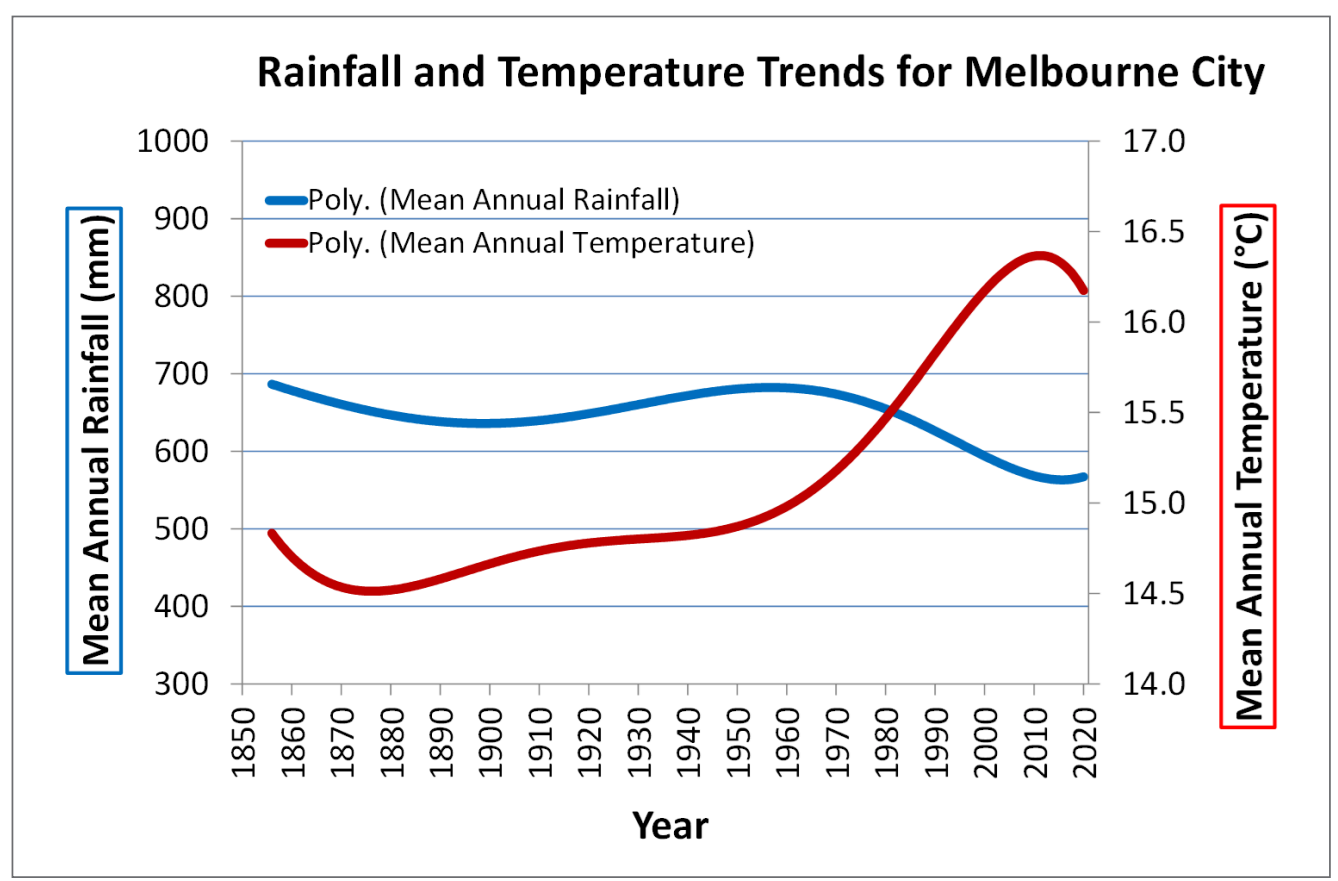

Fig. 2 Simplified scatter plot (points removed) of annual temperature and precipitation trends for Melbourne. Data sourced from Australian Bureau of Meteorology (2021b). Note that Melbourne's official weather observation station was relocated in 2015 and that 2020 was substantially wetter than average (Australian Bureau of Meteorology, 2021a). These changes are likely to have momentarily affected the temperature trend. Chart: P Symes.

respectively (Clarke et al., 2019). Based on the 1986-2005 mean annual temperature of $15.9^{\circ} \mathrm{C}$, the realisation of an RCP8.5 scenario may then result in a mean annual temperature of up to $19.3^{\circ} \mathrm{C}$ (Clarke et al., 2019). As background mean temperatures increase, extreme temperatures become more likely (CSIRO \& BOM, 2020). It is projected that, by that point, Melbourne could have up to twice as many days over $35^{\circ} \mathrm{C}$ (from 8.3 to 16 days under RCP8.5) (Clarke et al., 2019) and four times as many days over $40{ }^{\circ} \mathrm{C}$ (from 1.6 to 6.8 days under RCP8.5) (Webb \& Hennessy, 2015).

Note that projected global temperature rises found in the RCP8.5 scenarios may be unrealistically high (Forster et al., 2020) and are disputed by some authorities, who suggest that rises of $3^{\circ} \mathrm{C}$ above pre-industrial levels could be more likely by the turn of the century (Hausfather \& Peters 2020). RBGV approached this risk to the landscape by applying a 'precautionary principle' (Read \& O'Riordan, 2017), noting that carbon emissions were already tracking at high-level scenarios (Peters et al., 2013; Schwalm et al., 2020), that additional urban heat had not been factored into the projections (Huang et al., 2019) and that over 500 taxa in the collections that had originated from estimated median annual temperatures higher than $19{ }^{\circ} \mathrm{C}$ were growing well (RBGV, 2021b). This indicated that considering plant selection from origins with higher temperatures was more likely to be sustainable when contemplating temperature rise in the multi-decade time frames of landscape management.

Applying the same RCP4.5 and RCP8.5 scenarios, median values of precipitation 
are projected to decrease by 8-20 per cent and pan evaporation increase by 18.9-34.4 per cent respectively (Clarke et al., 2019). Even under the RCP4.5 scenario, demand for annual supplementary irrigation could increase by about 27 per cent, rising to over 50 per cent in an RCP8.5 scenario. Significant reductions in precipitation are projected for the cooler seasons of the year; spring is subject to the worst reductions with a drop of 18-30 per cent (Clarke et al., 2019). These seasonal changes may already be trending. Since the 1990s, a decline in rainfall of about 12 per cent has been observed for April-October (autumn to spring) in the south-east of Australia (CSIRO \& BOM, 2020). As the cooler periods are typically when lake systems are recharged for the next irrigation season, these changes to rainfall impact the current stormwater harvesting schemes in Melbourne Gardens.

\section{Climate change and threats to plant biodiversity}

The IPCC (2014) outlines (high confidence) that biodiversity richness faces significant threats to survival from climate change and, as quoted, 'A large fraction of species faces increased extinction risk due to climate change during and beyond the 21st century, especially as climate change interacts with other stressors.' If global warming can be limited to $1.5^{\circ} \mathrm{C}$ compared to pre-industrial levels (only $0.6^{\circ} \mathrm{C}$ above current), it is estimated that 8 per cent of plants could lose half of their climatically defined geographic range - this loss doubles to 16 per cent if warming results in a $2{ }^{\circ} \mathrm{C}$ increase (IPCC, 2018). Warren et al. (2018) suggest that 44 per cent of plants could lose more than half of their climatically defined range for a warming of approximately $3.2^{\circ} \mathrm{C}$ above pre-industrial levels. Within Australia, 47 per cent of the natural vegetation is estimated to be at potential risk from an increase in mean annual temperature of up to $3.3-3.4^{\circ} \mathrm{C}$ by 2070 (Gallagher et al., 2019). Cultivated environments such as botanic gardens, parks and gardens are also threatened as many trees appear confined to climatic envelopes and are likely to face additional warming stress from UHI effects (Kendal et al., 2018). Burley et al. (2019) report that, in Australia, the climatically suitable habitat will be reduced for 73 per cent of urban trees that were studied, and for 18 per cent of these species there could be a reduction in climatic range of more than 50 per cent.

The ability to track effective plant migration in response to changes in temperature and precipitation is constrained by altitudinal and geographic limits (Costion et al., 2015; Christmas et al., 2016), and many species cannot shift their geographical ranges rapidly enough to respond to rates of climate change (IPCC, 2014; Corlett, 2016; Booth, 2017). For example, in Australia, Eucalyptus spp. have been noted as having relatively poor mechanisms for effective dispersal, with estimated migration rates of only 1-2 m each year (Booth, 2017) - well below a theoretical range shift when future temperature rise is considered. This is further confounded with the higher risks of extinction-level events such as wildfires (Harris et al., 2018) and heatwaves (Ruthrof et al., 2018). Estimates of global plant extinction are already significant due to habitat loss, invasive species and other human-mediated activities, and climate change brings yet another threatening process to the fore (Pimm \& Raven, 2017). More recent estimates suggest that 39 per cent of the world's plants could be threatened by extinction, however this does not necessarily factor in the future risks from climate change (Nic Lughadha et al., 2020). 
Elevation and range shift risks for Australian plant biodiversity

Risks to plant biodiversity in an Australian context can be demonstrated by examining the limits to montane vegetation. At an average elevation of only $330 \mathrm{~m}$, Australia is the lowest continent in the world. The mountains in other continents can be more than twice as high as Mount Kosciuszko $(2,228 \mathrm{~m})$, Australia's tallest peak. In fact, less than 1 per cent of Australian land surface area has an elevation greater than $1,000 \mathrm{~m}$ (Geoscience Australia, 2021). Numerous authors have reported on elevation range shifts in montane vegetation - either upwards, presumably in relation to temperature increases (Harsch et al., 2009; Lenoir et al., 2010; Dirnböck et al., 2011), or downslope in response to shifts in vegetation competition and water availability (Crimmins et al., 2011; O'Sullivan et al., 2021), but the causal components appear to be more complex and go beyond climatic drivers alone (Naccarella et al., 2020; O'Sullivan et al., 2021). Eucalyptus pauciflora (snow gum) (Fig. 3 ) is an iconic Australian species that typically grows at elevations from $700 \mathrm{~m}$ (Atlas of Living Australia, 2021) to the alpine treeline at about 1,750-1,900 m (Naccarella et al., 2020). There is evidence that some upslope migration is occurring as temperatures warm (Brookhouse \& Bi, 2009; Naccarella et al., 2020), but perhaps in contrast to other areas of the world, Australia's alpine regions are also prone to bushfires that complicate the current understanding of vegetation dynamics (Camac et al., 2017). Hoffmann et al. (2019) report on studies conducted on Mount

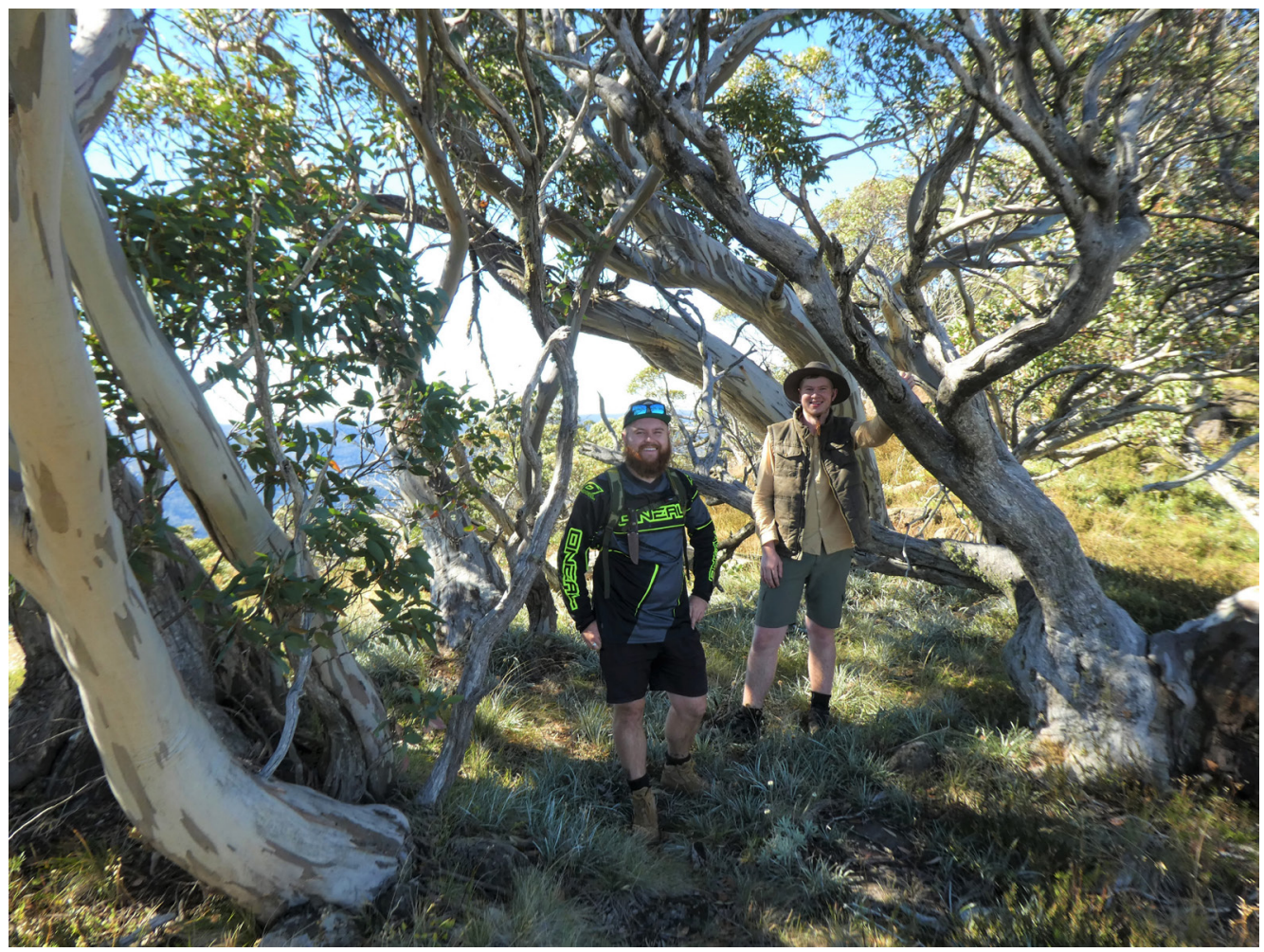

Fig. 3 Typical gnarly forms of Eucalyptus pauciflora (snow gum) off King Billy Track, near Mount Howitt, Victoria. Photo: P. Symes. 
Bogong in the Victorian high country that indicate the combination of more frequent burning (mediated by climate change) and subsequent dominance of shrubby life forms could displace snow gums, as well as alpine grasses and forbs. There are conceivably many areas where snow gums and other species could be constrained by lower peaks and have limited flexibility to redistribute to optimum ecological niches in response to these environmental and competitive pressures (Hughes, 2011).

\section{Bushfire risks}

The warming and drying effects resulting from climate change can increase the frequency and severity of fires (Jones et al., 2020), and so in turn increase the risk they present to plant diversity. These intensifying conditions can also impact recruitment cycles and vegetation succession even in fire-adapted vegetation (Bowman et al., 2014). In southern Australia, Forest Fire Danger Index values have been increasing since the 1950s, and current projections suggest that fire seasons will commence earlier and that fire events will be more frequent and more severe, and of longer duration (CSIRO \& BOM, 2020; Mackey et al., 2021). In 2019-2020, Australia faced unprecedented fires (Mackey et al., 2021) where almost 19 million ha were burned (Filkov et al., 2020). These extensive fires burned significant areas of land in the eastern part of the State of Victoria (Fig. 4), and their extent and ferocity may be a harbinger of a shift in fire regimes towards more severe events. Between 60 and 90 per cent of Victorian taxa were impacted by these fires (Gallagher, 2020). Ongoing recovery work was implemented by RBGV and the Department of Environment, Land, Water and Planning to collect seed and propagate accessions of the most threatened taxa.

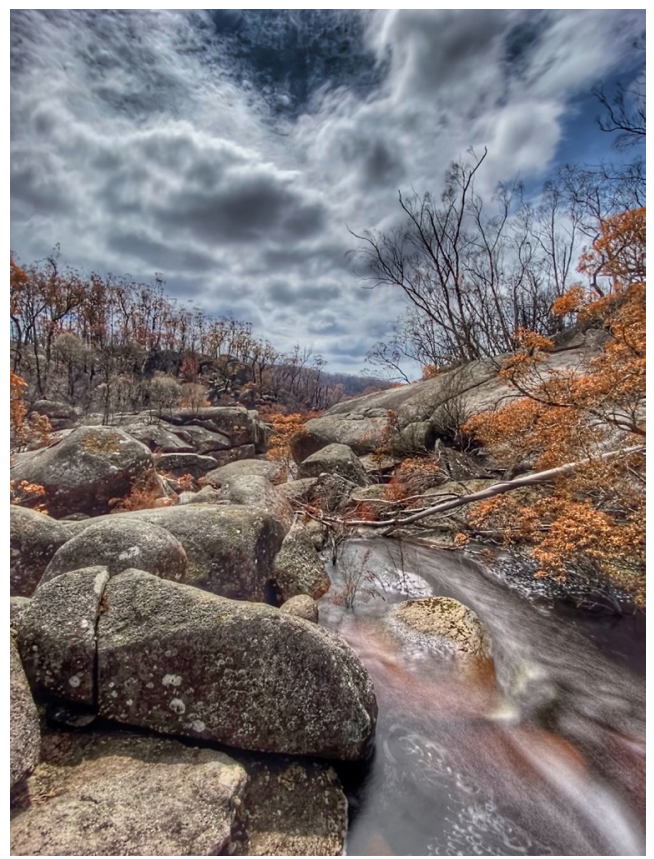

Fig. 4 Victorian bushfires burned over 1.2 million ha in the east of the State of Victoria between late 2019 and early 2020 (Godfree et al., 2021), severely impacting both terrestrial and associated freshwater ecosystems such as this scene of the Genoa River. Photo: N. Clemann.

\section{Pests and diseases}

Other stresses that may be affected by climate change include pests and diseases. Such effects may manifest as new pest incursions, increased severity of existing pest outbreaks, or conversely a reduction in the severity of existing problems (Pautasso et al., 2012; Hunjan \& Lore, 2020). In Australia, there are concerns about potential latitudinal and elevational range shifts under climatic change for Phytophthora spp. with special reference to alpine areas (Cahill et al., 2008; Burgess et al., 2019). The more commonly known $P$. cinnamomi already affects plants in mountainous South West Australia (Barrett \& Yates, 2015). About 50 per cent of known pathogenic taxa in Australia are exotic species (Burgess et al., 2019) and how some of these pathogens will interact with new suitable environments and hosts could reflect the 
literal meaning of Phytophthora as 'plant destroyer'.

In April 2010, myrtle rust (Austropuccinia psidii) was first reported in Australia (Carnegie et al., 2010). This disease is limited to infecting taxa in Myrtaceae and damages soft plant tissues such as new shoots, leaves, flowers and fruits, resulting in leaf deformation and lesions, defoliation, reduced seed viability, dieback, stunted growth and ultimately death for some taxa (Pegg et al., 2018). Australian taxa probably account for more than 50 per cent of the world's species in Myrtaceae (ANBG, 2021). Myrtle rust is well established along most of the eastern coastal regions of Queensland and New South Wales (particularly in warm temperate, subtropical and tropical regions) and parts of the Northern Territory, and only marginally established in Victoria and Tasmania. Over 380 Australian taxa are potentially at risk from infection, with 43 severely affected
(Makinson et al., 2020). The disease has impacted some relatively common species in their natural range so severely that two taxa (Rhodomyrtus psidii and Rhodamnia rubescens) are now listed as Critically Endangered (Makinson, 2018; Sommerville et al., 2020). In April 2013, myrtle rust was first detected at RBGV's Melbourne Gardens on Lophomyrtus obcordata (Fig. 5) and has since appeared on this and other host plants (mostly Myrtus communis, Lophomyrtus spp. and $R$. rubescens) for six of the last ten years - mostly in autumn. It is not clear whether climate change will increase the severity of this disease in Victoria as it requires suitable conditions of leaf wetness, hours of darkness and optimum temperatures to infect (Makinson, 2018). However, the optimum temperature range of $15-25^{\circ} \mathrm{C}$ for development of myrtle rust and some climate niche models (Berthon et al., 2018; Makinson, 2018; Narouei-Khandan et al., 2020) suggest

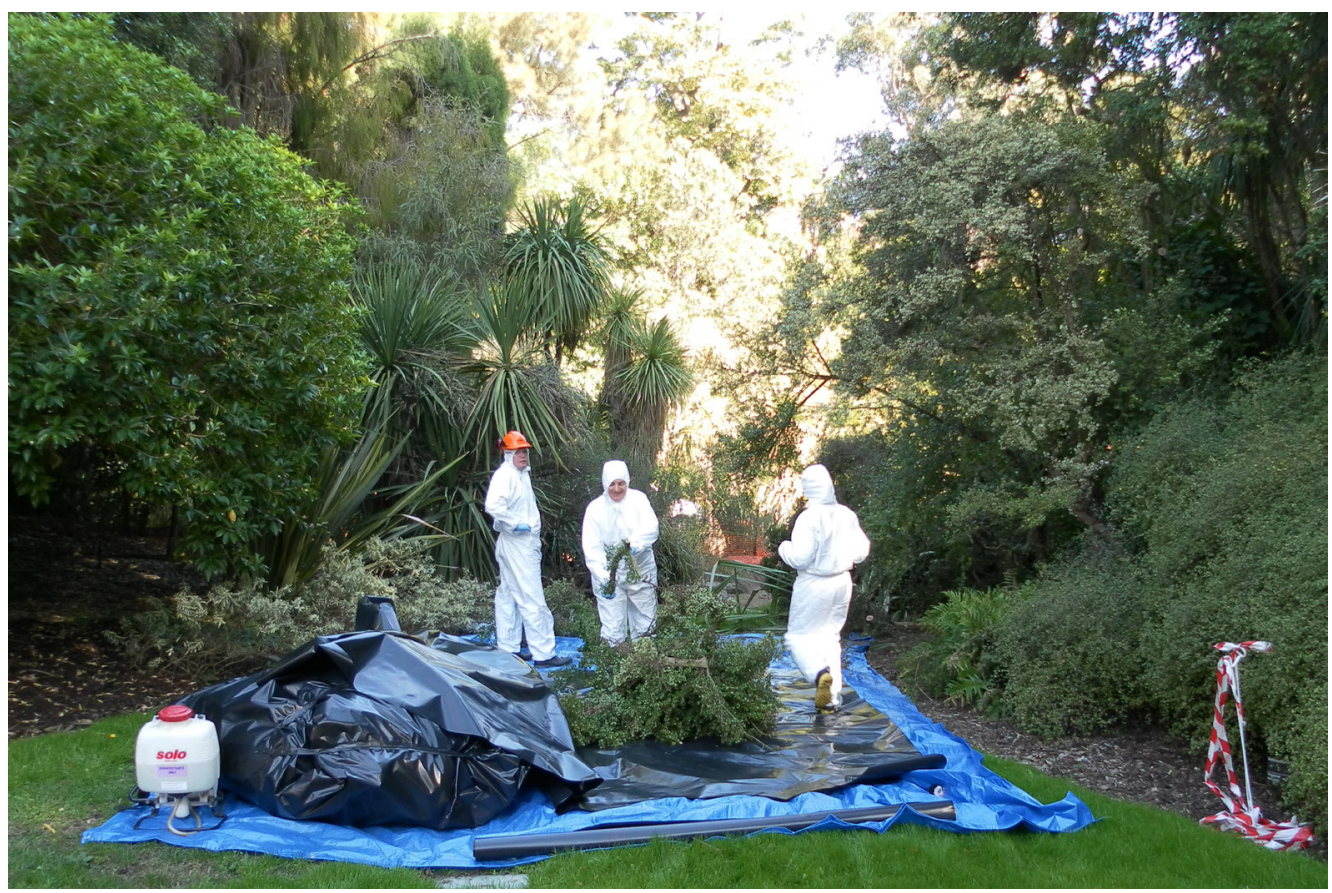

Fig. 5 A specialist team also involving horticulturists tackling the first myrtle rust incursion in Melbourne Gardens. Photo: P. Symes. 
that global warming may provide new environments or seasonal shifts that support the proliferation of this disease in Victoria.

\section{The Landscape Succession Strategy}

RBGV has included climate change responses in its strategic planning since the 1990s, particularly during the Millennium Drought of 1997-2010 (CSIRO, 2012). During this period, the organisation improved water-use efficiency and reduced water consumption by $40-50$ per cent (Symes \& Connellan, 2013), yet still safeguarded its living collections and landscape. Nevertheless, the publication of a series of climate change projections (CSIRO, 2008; Grose et al., 2015) and the occurrence of alarming heatwaves (Department of Health, 2014) highlighted a need for more robust planning in response to climate change.

There were two questions to consider in justifying further plan development.

1. What was the actual risk to the living collections?

2. Could this risk be mitigated by microclimate-based plant selection?

Firstly, a preliminary climate audit of the living collection holdings was undertaken by horticulturists, which matched KöppenGeiger climate classifications (Rohli et al., 2015) with known plant distributions according to geographic zones defined by Brummitt et al. (2001). They found that about 35 per cent of taxa were considered to be at the highest level of risk from projected climate change (Symes, 2017). Secondly, a landscape microclimate analysis was carried out to determine if site selection could be used to mitigate temperature rise. It was concluded that cooling potential from most sites was inadequate to counter the more extreme mean annual temperature increases of $3{ }^{\circ} \mathrm{C}$ projected by 2090 (Grose et al., 2015; Symes, 2017). While selection of landscape microclimates can modify exposure to solar radiation and wind, and, to some extent, can mitigate the effects of more extreme temperatures, there are considerable constraints in applying this tactic across entire landscapes (Symes, 2017). These results indicated an urgent need to develop an integrated and strategic response to climate change.

In April 2016, the Landscape Succession Strategy - Melbourne Gardens 2016-2036 was publicly released (RBGV, 2016). This 20-year strategy aims to respond to climate change risks by guiding the transition of Melbourne Gardens from existing plantings to a landscape collection better suited to the projected climate and environmental conditions of 2090.

Notably, horticulturists in Melbourne Gardens had a pivotal role in design workshops and in developing and writing the technical content of the Landscape Succession Strategy (LSS). Strategic plan development can involve significant input from consultants or other experts, and these financial costs may be perceived by some as limiting any planning for a climate future. Successfully involving horticulturists in such an important undertaking showcases the LSS as a realistic and valuable study of what is achievable for any arboretum or botanic garden.

Development of the LSS included seeking best practice examples of landscape adaptation plans through a worldwide literature review and obtaining industry feedback via forums such as Linkedln Botanic Gardens Professionals (more than 5,000 members) and Linkedln Horticulture (more than 40,000 members). This review revealed 
a confronting gap in knowledge regarding effective strategic management of cultural landscapes and living collections through a climate change lens (Symes, 2017).

The LSS applies a paradigm for the managed change of the Melbourne Gardens vegetation. This model is based on ecological theories that define plant succession, such as changes in the composition and structure of vegetation communities over temporal scales following a disturbance threshold (Prach \& Walker, 2019).

Key requirements identified by the LSS are as follows:

\section{Adapt the landscape and its living} collections to promote greater resilience for the projected 2090 climate.
2. Act now as the evaluation, selection and establishment of long-living assets such as trees require predictive decision making in advance of future conditions.

3. Safeguard the educational, recreational and scientific value

of Melbourne Gardens for future generations.

Resilience has been defined as 'learning how to change in order to stay the same' (Walker, 2019). This is a prime goal of the LSS. When visitors arrive at Melbourne Gardens in 70 years' time, they will experience a similar world-class landscape - one that retains its heritage character (Fig. 6), landscape qualities and plant diversity for future generations.

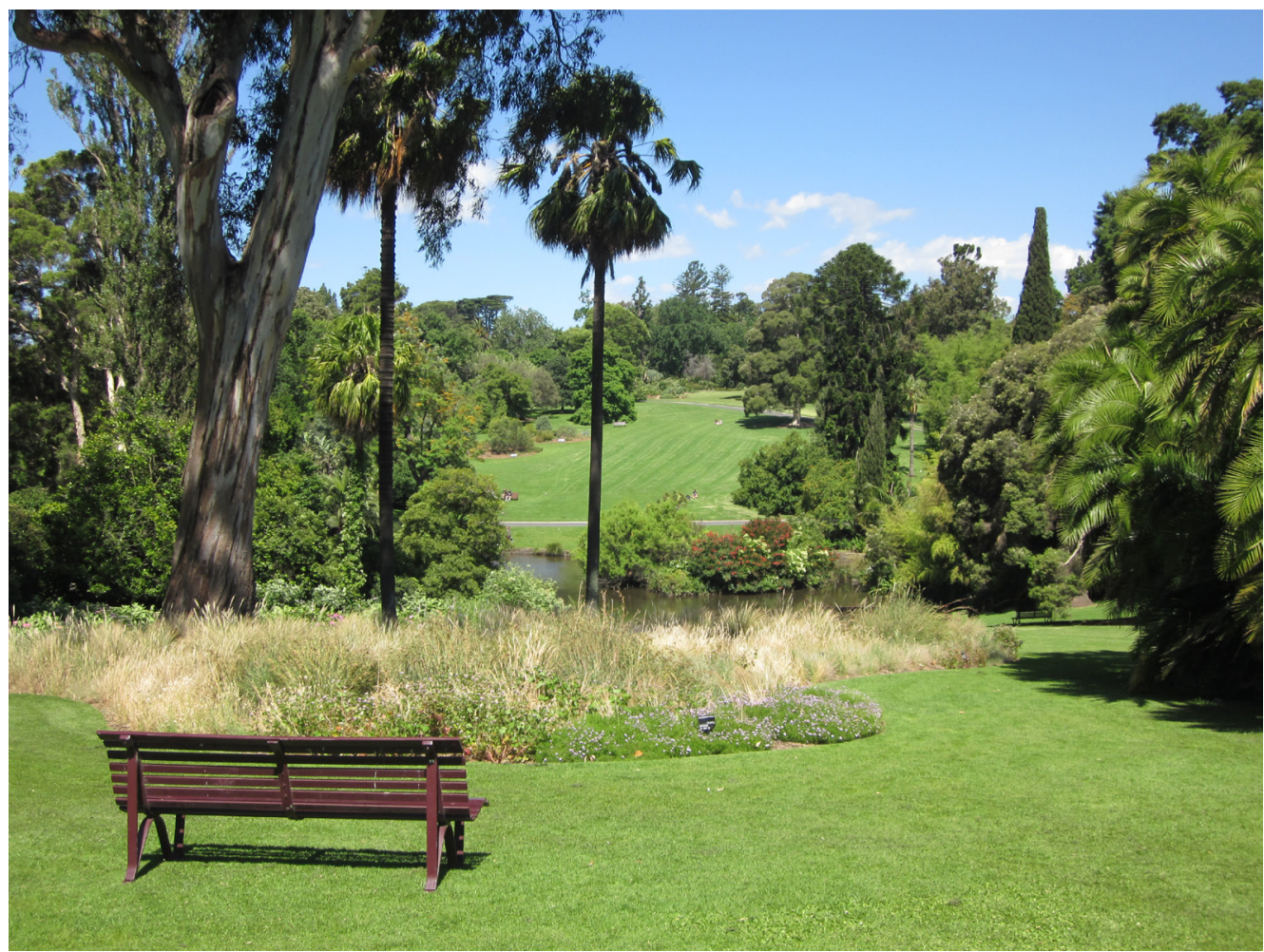

Fig. 6 The heritage landscape of Melbourne Gardens as seen from Princes Lawn, developed by William R. Guilfoyle in the 'picturesque' landscape style following his appointment as Director of the Royal Botanic Gardens, Melbourne in 1873. This involved major landscaping work that was completed in 1879, but otherwise continued incrementally over a period of 35 years. Photo: P. Symes. 
Implementation of the Landscape Succession Strategy

Assessment of the climate change risk to the living plant collections

In early 2017, researchers at the University of Melbourne were commissioned to analyse the climate risks faced by the living collections. Data sources included species occurrences from the Global Biodiversity Information Facility (GBIF) (GBIF.org, 2021), which currently holds over 330 million Plantae occurrences, 2,700 taxa from 400 urban plant inventories from cities around the world (Kendal \& Farrar, 2017) and bioclimatic variables (BIOCLIM) from WorldClim (Hijmans et al., 2005). BIOCLIM parameters (19 in total) are derived from monthly temperature and precipitation values to generate variables that define the climate envelopes of ecological niches (Pearson \& Dawson, 2003; Booth et al., 2014).

For Melbourne Gardens, the BIOCLIM parameters used in the analysis included: BIO1 - Annual Mean Temperature; BIO5 - Max Temperature of Warmest Month; BIO1 1 - Mean Temperature of Coldest Quarter; BIO12 - Annual Precipitation; and BIO17 - Precipitation of Driest Quarter (Kendal \& Farrar, 2017). BIO1 - Annual Mean Temperature was used for the primary risk assessment as it was determined to be a robust proxy for enumerating temperature ranges of cultivated species (Kendal et al., 2018). Other BIOCLIM values, such as BIO12 - Annual Precipitation, were selected to inform decision making. Precipitation has not been shown to be a strong predictor of climatic suitability in urban plantings and this risk is also deemed to be more manageable through irrigation (Kendal et al., 2018).

The risk assessment examined the current climate, and RCP4.5 and RCP8.5 emission scenarios for climate projections in 2050 and 2070 , including an estimate of urban heat increase. For the relevant bioclimate variables, percentile distributions were calculated for natural and cultivated plant distributions. In the instances at which Melbourne's temperature scenario was warmer than the 90th percentile, taxa were considered at high risk from climate change, with highest risk allocated for taxa above the 97.5th percentile (Kendal \& Farrar, 2017).

With temperatures as they are in 2021, about 12 per cent of the current taxa in Melbourne Gardens are ranked most at risk. For the projected RCP8.5 climate scenario by 2070 , with an annual temperature of $19.3^{\circ} \mathrm{C}$, this risk increases to 26 per cent for all taxa assessed (Fig. 7) (Kendal \& Farrar, 2017).

While these results and their spatial representation can appear alarming, they provide a useful tool for landscape planning. Identifying vulnerable taxa and spatial extents means proactive collection development and management can take place in advance of any potential decline of the holdings. Further, this assessment identifies new opportunities for plant selection, displays and research. As an example, another study commissioned by RBGV carried out a global climate risk analysis of rare and threatened plants and found that about 3,000 taxa were potentially well suited to the future climate scenarios for Melbourne (Kendal, 2017).

\section{Global representation in the collection} Strategic planning for the living collections sought to define the range of geographic regions with climatic parameters comparable to Melbourne's future. Spatial BIOCLIM layers of BIO1 - Annual Mean Temperature and BIO12 - Annual Precipitation (Fick \& Hijmans, 2017) were processed in Geographic Information Systems (GIS) against spatial layers according to the World Geographical Scheme for Recording Plant Distributions 


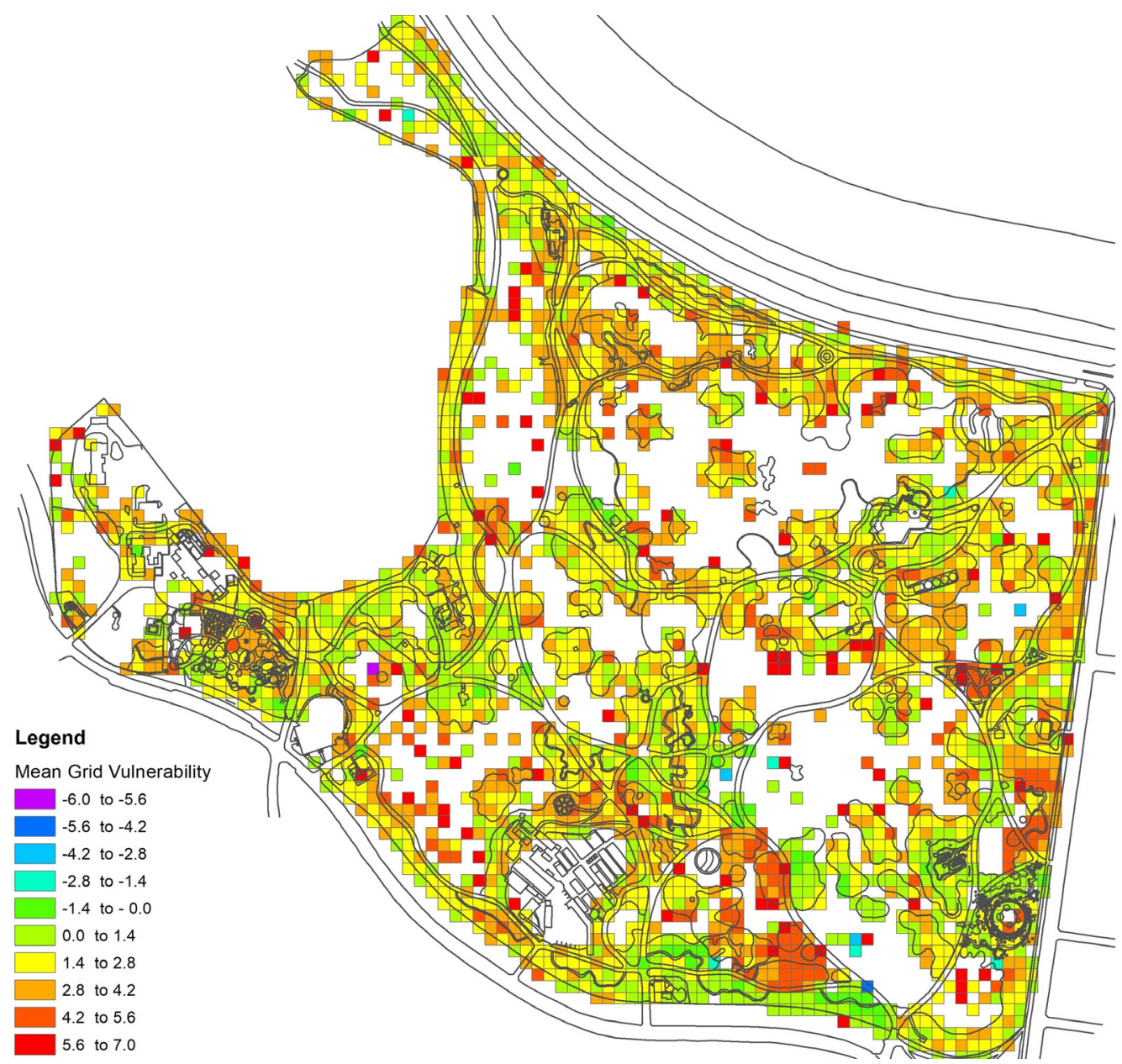

Fig. 7 A spatial representation of Melbourne Gardens landscape risk in the extreme climate scenario of 2070, with an increase in mean annual temperature to $19.3^{\circ} \mathrm{C}$ (Kendal \& Farrar, 2017); red indicates the highest risk, green is considered an acceptable risk. Map: P. Symes.

(Brummitt et al., 2001). This simple selection was based on an intersecting overlay comprising an annual mean temperature range of $17-21^{\circ} \mathrm{C}$ and annual precipitation of $200-1,100 \mathrm{~mm}$ to highlight potential collecting zones (Fig. 8). Out of the top five countries, Australia has approximately 29 per cent of the potential climate-matched geographic area, while Argentina (9 per cent), South Africa (8 per cent), Mexico (8 per cent) and the USA ( 8 per cent) share about 33 per cent of the total. To inform decision making, these analyses using GIS layers can be customised to combine different bioclimatic parameters, vegetation types, geography, biodiversity hotspots, and so on.

Furthermore, this analysis emphasises the capacity to assist with global plant conservation efforts. Some plant species may already be vulnerable to changing climatic conditions in their natural habitat and current ex situ collections in botanic gardens. For these taxa, Melbourne Gardens could provide a better growing environment now, or in the future, to safeguard plants threatened by rising temperatures in their original climates. 


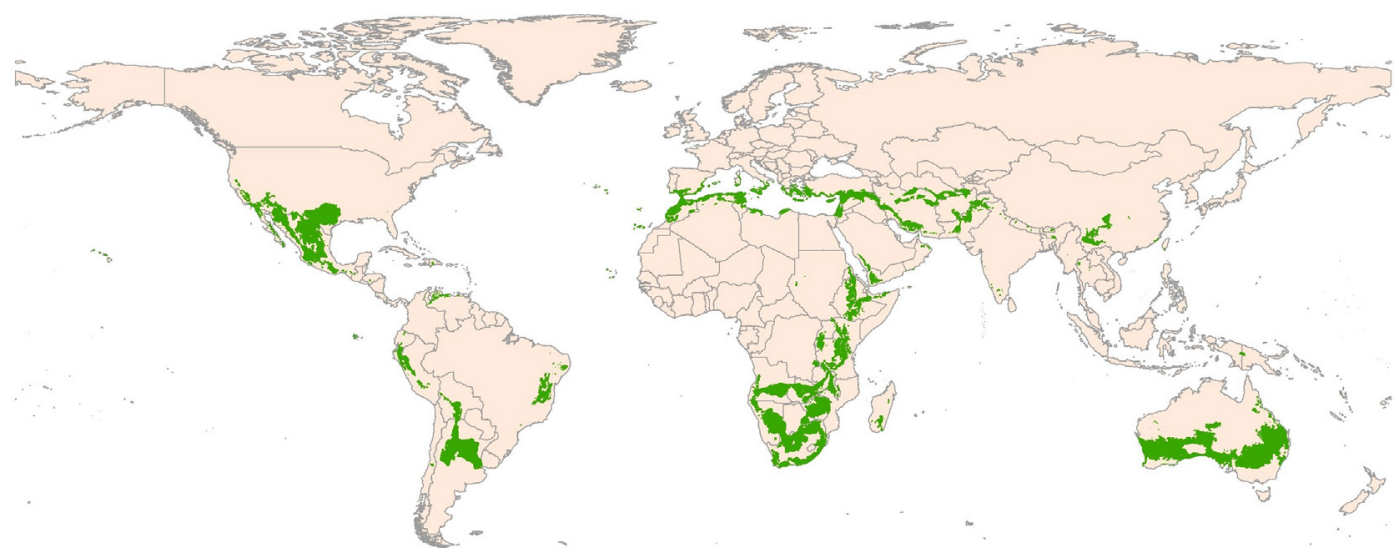

Fig. 8 Map of world regions showing intersects of the following parameters: BIO1 of $17-21^{\circ} \mathrm{C}$, and $\mathrm{BIO} 12$ of $200-1,100 \mathrm{~mm}$. Data sourced from Brummitt et al. (2001) and Fick \& Hijmans (2017). Map: P. Symes.

\section{Case study: Australian Forest Walk}

The Australian Forest Walk collection probably owes its origins to the strong interest of two eminent early Directors of RBGV: Ferdinand Von Mueller (Gardens Director 1857-1873 and collector of over 28,000 Australian voucher specimens) and William R. Guilfoyle (Gardens Director 1873-1909). Under Guilfoyle's directorship, the 'Australian Border' is believed to have been started in 1887 with a planting of 400 native trees and shrubs. Today, this collection of 1,395 accessions and 583 taxa covers almost one hectare and extends for half a kilometre along the southern boundary of the Gardens. However, the advent of the Millennium Drought (1997-2010), overall annual rainfall decline and projected climate change threaten the composition of taxa.

Current responses to climatic change include Australia-wide collecting expeditions on a scale not seen in over two decades, with the aim of diversifying holdings with more climate-suited taxa. GIS analyses of spatial layers of BIO1 - Annual Mean Temperature and BIO12 - Annual Precipitation (Fick \& Hijmans, 2017) identified substantial areas in New South Wales (NSW) and Queensland.
The fine-tuning of these evaluations was undertaken by the horticultural curator, Gemma Cotterell (and others from RBGV), in collaboration with experts from other organisations including the Queensland Herbarium and the Royal Botanic Gardens and Domain Trust, Sydney. In early 2020, the first field expedition to NSW (Fig. 9) obtained about 60 taxa likely to be more suitable for cultivation in Melbourne. Some of these are dry rainforest species which are potentially less suited to other ex situ conservation techniques such as seed banking. Strong working relationships and sharing information have now led to positive safeguarding outcomes for threatened species across multiple states.

From her personal experience, Gemma states, 'In response to climate change we are undertaking collecting trips to forests of Australia that exhibit climates like those predicted for Melbourne's future. By planting wild-collected plants from a known provenance, I am transitioning the collection, and building the resilience of the Australian Forest Walk as well as the broader Melbourne Gardens landscape. I have collaborated with interstate botanic gardens and herbaria in 
planning trips and sharing propagules as part of this work, supporting plant conservation efforts across Australia by aiding with seed banking, metacollections and bushfire recovery programs' (Gemma Cotterell, pers. comm.).

\section{Case study: New Zealand Collection}

The collection of plants native to New Zealand has significant heritage importance as it was created as one of the last landscape developments of W.R. Guilfoyle (completed in 1908). Most species native to New Zealand originate from significantly cooler, wetter conditions than can be expected in Melbourne, both currently and in the future. Climate risk assessments highlighted the potential climate vulnerability of the collection as 67 per cent of taxa are considered at highest risk from temperature increases by 2090 (Fig. 10).

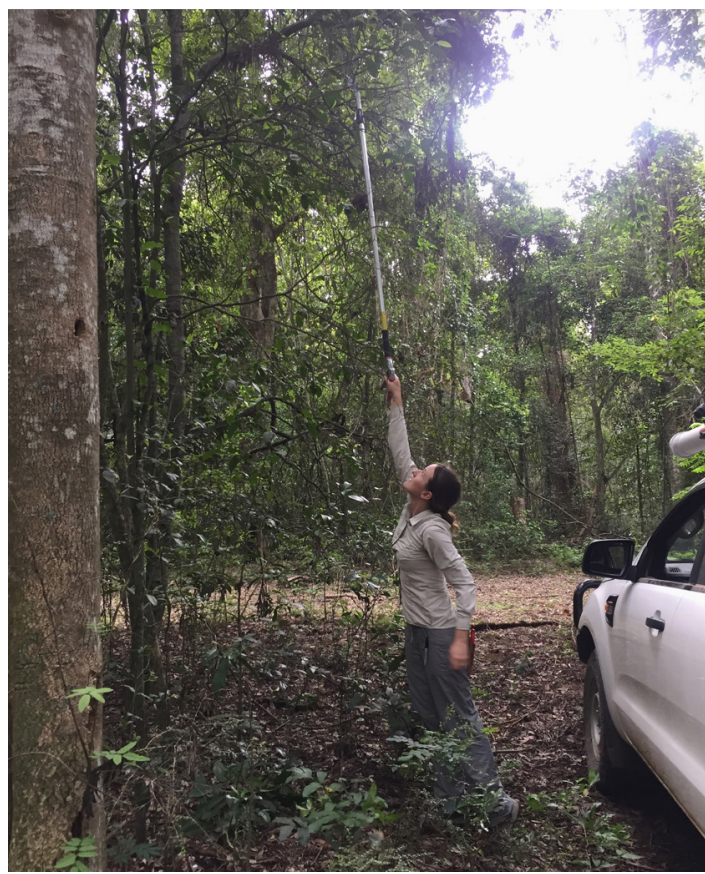

Fig. 9 Gemma Cotterell collecting material from Ixora beckleri (brown coffeewood), Pikapene National Park in north-east NSW. Photo: G. Phillips.

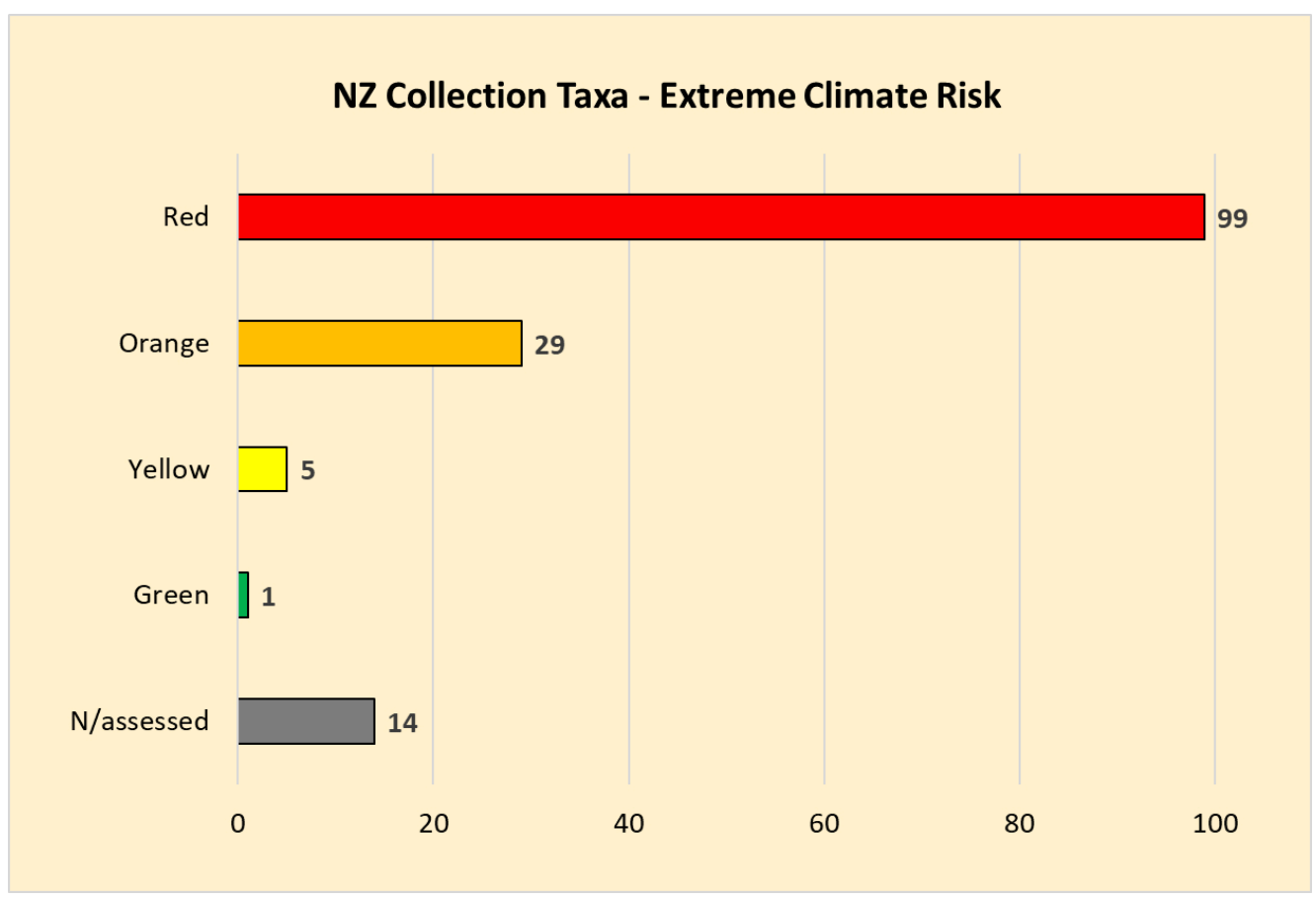

Fig. 10 A chart showing the climate risk for known New Zealand taxa (excluding cultivars) in the living collection against the extreme climate scenario of 2070 , with an increase in mean annual temperature to $19.3{ }^{\circ} \mathrm{C}$ (Kendal \& Farrar, 2017); red-coded results present the highest risk. Graph: P. Symes. 
In response, the horticultural curator of the collection, Kate Roud, has built strong relationships with members of the New Zealand Plant Conservation Network and other botanic gardens in New Zealand to share information and expertise, and is working with Māori representatives to procure seed from habitat. For species currently impacted by heat, such as Meryta sinclairii (puka), Kate is also experimenting with different microclimate placements for some taxa to reduce the effects of excessive solar radiation and dryness.

Opportunities for these at-risk plantings include research programmes to identify actual taxon vulnerability and, perhaps more interestingly, consideration of the value of these collections and their plants as proxy indicators of climate change vulnerability to inform other colleagues in the species' countries of origin.

Climate change impacts upon plant biodiversity, and conservation of that biodiversity cannot be separated from indigenous people and their traditional knowledge (Cámara-Leret et al., 2019; Wehi et al., 2019). Kate has a deep understanding of this connection and states, 'The Aotearoa/ New Zealand Collection continues to teach me about climate change and culture. The connection of Māori people, culture and language to the earth and nature is deep and enduring. We, all of us, are "kaitiaki" guardians. Papatūānuku, Mother Earth, is calling to us. It's time to listen and act.' (Kate Roud, pers. comm.).

\section{Key role of horticultural curators in climate change responses}

Many botanical authors champion the role of botanical horticulturists in the field of 'botanical or conservation horticulture' and the importance of supporting professional development in botanic gardens (Rae, 2013; Gratzfeld, 2017). In Melbourne Gardens, horticultural curators contributed significantly to the success of international ventures such as the Climate Change Alliance of Botanic Gardens (Martín et al., 2020) and, to facilitate the development of collections, have effectively engaged with donors, senior executives and scientists from other organisations across the world. This horticultural capacity to engage at multidisciplinary levels of varying seniority is a strength when it comes to responding to climate change in an expedient and effective manner.

\section{Climate Change Alliance of Botanic Gardens}

In its outreach aims, the LSS emphasised the need to 'improve understanding of the impacts of climate change on botanical landscapes' and to 'lead and facilitate networks and partnerships with relevant organisations in landscape-related conservation of biodiversity, human health, urban greening and water management' (RBGV, 2016).

\section{Climate Change Summit and formation of the Climate Change Alliance of Botanic Gardens}

In December 2018, colleagues from a diversity of cultures, languages and organisations around the globe attended the botanical world's first Climate Change Summit, held at RBGV, Melbourne (RBGV, 2021a). The participants attended a series of presentations, workshops and field tours that had an emphasis on the impacts of climate change on plants and landscapes. It was clear that the profound complexity and 
scale of addressing climate change requires global collaboration and the engagement of an abundant diversity of expertise - qualities that are intrinsic to a botanical gardens ${ }^{4}$ network (Primack \& Miller-Rushing, 2009; Martín et al., 2020). In response to the now unavoidable changes in climate, it was agreed that the 'time for action is now', and a declaration was signed to 'safeguard life by protecting landscapes. This Melbourne Declaration led to the foundation of the Climate Change Alliance of Botanic Gardens ('the Alliance') (RBGV, 2021a).

\section{Purpose and principles of the Alliance}

Botanic gardens worldwide are stewards of landscapes and living collections that are interconnected with critically important plant diversity. In responding to a recognised knowledge gap (Symes, 2017), the current focus of the Alliance is to build the global capacity of botanic gardens to safeguard landscapes and living collections through a changing climate.

Through biomimicry, plants and landscapes can provide useful regenerative models (Zari, 2018) to establish a network that remains contemporary to both the members and matters of concern. On this premise, the following principles of the Alliance were deliberately adopted from living systems models (Karl, 2012) to combine landscape sustainability, ecology and social networks (Opdam et al., 2018). These principles are expected to nurture an Alliance that is adaptive, diverse and resilient, thriving in the face of boundless change.

\footnotetext{
${ }^{4}$ The terms 'botanic gardens' and 'botanical gardens' in this paper include botanic gardens, arboreta and other botanical landscapes that hold plant collections.
}

Principle 1 - self-organisation around a shared purpose

Complex living systems exhibit a self-organising pattern in response to their environment (Negru, 2018). As part of a thriving, complex social-ecological system (Bodin et al., 2016), this self-organising configuration in combination with a clear, shared purpose is expected to promote leadership that creates regional and global impacts.

\section{Principle 2 - recruit for and celebrate diversity \\ In the context of botanic gardens, diversity is a readily identifiable characteristic of healthy natural and social systems (Dunn, 2017). Pursuing a high diversity of Alliance membership builds in adaptive capacity and support.}

\section{Principle 3 - maintain momentum and energy flows}

Social networks are better assisted when an active rhythm is established to share expertise and resources concurrent with changing circumstances (Barnes et al., 2017).

\section{Principle 4 - nurture relationships}

Social capital is built when the number and quality of relationships between members of the Alliance is increased (Sumanarathna et al., 2020). Stronger relationships are likely to equate to a stronger Alliance (Fig. 11).

\section{Principle 5 - plan for resilience and adaptability \\ The level of resilience and adaptive capacity (Walker, 2019) to maintain the goals and values of botanic gardens over time is a measure of success of these principles.}




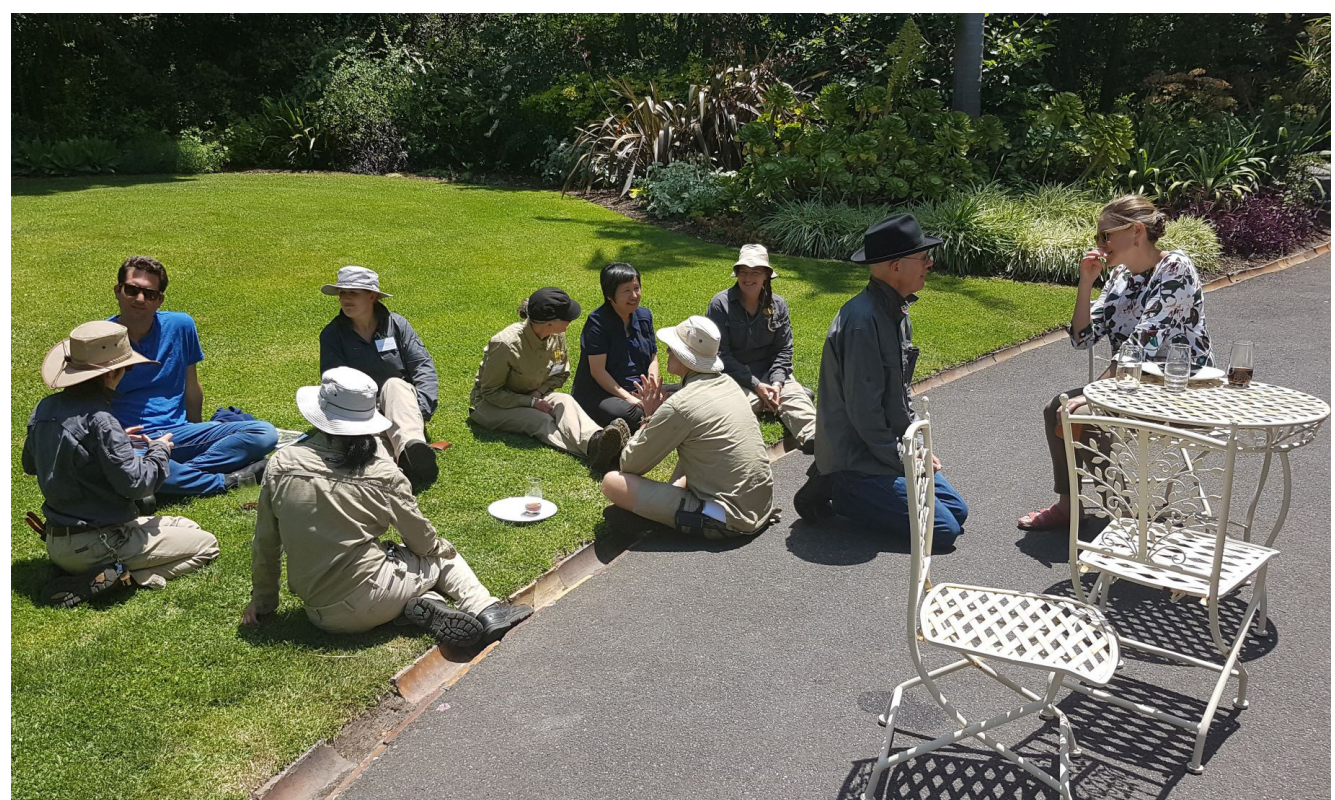

Fig. 11 Some of the founding members of the Alliance sharing experiences with arborists and horticulturists of Melbourne Gardens during the Climate Change Summit. Even these informal discussions led to strengthening relationships beyond one event. Image: P. Symes.

\section{Selected benefits of the Alliance} Integrated and intergenerational context Arboreta and botanic gardens as typically urban landscapes can be defined as complex social-ecological systems (Martín-López et al., 2017; Steenberg et al., 2019). This intricacy is challenged by a changing climate, uncertainty and limited understanding of the future dynamics of shifting interactions. The Alliance brings a globally integrated wealth of cultural diversity, perspectives and expertise to assist its members with landscape and living collections management, and provides a line of sight between shared best practices. Technical improvements achieved by Alliance members are readily transferred and supported by 'social learning' (Dickson et al., 2019). Social systems of learning can foster creativity, innovation and resilience, demonstrating high plasticity to predict needs, adapt to circumstances and adopt new solutions within shorter time scales (Gonzales-Iwanciw et al., 2019).

\section{Plant conservation}

Collectively, arboreta and botanic gardens hold about 30 per cent of the world's known plants (around 106,000 species) and contain 41 per cent of threatened species through ex situ conservation, although there are significant collection gaps in plant groups such as tropical species (Mounce et al., 2017). A global focus on the risks to vulnerable plants in collections and shared learning assists with the prioritising of further protection. There are also 'exceptional species' not suited for seed banking (Fant et al., 2016) - rainforest species (some), cycads, oaks and palms - that need to be curated as living specimens to conserve unique genotypes. Threatened plants may already be at risk from changing climatic conditions in habitat and ex situ collections in botanic gardens, whereas a better growing environment could be 
available now or in the future at other gardens and could be safeguarded through networked metacollections (Griffith et al., 2020).

\section{Environmental protection and services} In addition to safeguarding plant biodiversity, the Alliance can mobilise protection for botanical landscapes and advocate for plantbased solutions to support human wellbeing (Shanahan et al., 2015; Carrus et al., 2017); maintain landscape carbon sequestration (Webb, 2014); provide natural cooling against temperature rise (Ellison et al., 2017); provide habitat for urban biodiversity (Marselle et al., 2019); reduce noise and filter pollution (Haase et al., 2014); reduce damage from flooding and stormwater runoff (Livesley et al., 2016); and contribute to resilient urban greening (Cavender et al., 2019).

\section{Enhancing knowledge and expertise transfer through collaboration}

Botanic gardens provide unique contexts for climate change research with geographically diverse plant holdings, managed plant environments, and long-term monitoring and considerable staff expertise (Primack \& Miller-Rushing, 2009). Further, many plants are grown outside their natural range. This can demonstrate the 'fundamental niche' (Sax et al., 2013) or the potential of a given species to grow beyond its natural distribution when competition, dispersal limitations and other inhibitory factors are removed (Bush et al., 2018). Although cultivated environments may provide advantages for plant performance, species showing poor tolerance to climate change in these more favourable conditions could be even more at risk under the constraints of the natural habitat, for example species with specific germination temperature requirements (Sentinella et al., 2020). Members of the Alliance can share observations or organise custom research programmes to explore the tolerance range and to inform conservation priorities (Vincent et al., 2020). Botanical collections can also be used as indicators of climate change vulnerability even for plants that may not yet be currently threatened. For example, founding Alliance members established the Ibero-American Node of Botanical Gardens against Climate Change (NIJAB-CC) to combine the expertise of Spanish-speaking countries in phenological research across continents, using latitudinal gradients to study plant lineages more sensitive to climate change, and improving meteorological data and climate change indices (Real Jardín Botánico de Madrid, 2020).

\section{Community and social profile}

While botanic gardens have vast potential to communicate climate change issues and make societal impacts, it has been noted that they have lacked community visibility in this arena (Dodd \& Jones, 2010). A partnership such as the Alliance provides a global prominence for all members, regardless of their capacity or resources. Since its formation, members have already mobilised the interest of their communities, influenced positive action by governments and energised botanical networks. During the Melbourne Climate Change Summit in 2018, Jerusalem Botanical Gardens received news of a significant private funding pledge that was linked to their involvement at the event. The Carlos Thays Botanic Garden of the City of Buenos Aires enabled a parliamentary declaration regarding climate change. In Australia, the government of Victoria initiated the 'Growing Victoria's Botanic Gardens' grant (AU\$4 million over 2019 and 2020) that includes improving the climate change adaptation and resilience of regional botanic 
gardens (DEWLP, 2019). Opportunities abound to use botanic gardens as spaces to engage with the community through educational initiatives on climate change (Sellmann \& Bogner, 2013) and citizen science (Chen \& Sun, 2018).

\section{Flagship project: the Global Climate Risk Assessment Tool}

There is currently no widely available tool to assist botanic gardens in assessing the climate suitability of current and potential species in their living collections. The Global Climate Risk Assessment Tool ('the Tool') project is a world-first initiative to support arboreta, botanic gardens, urban forestry and horticulture in decision making by providing climatic data and risk assessment in GlobalTreeSearch (BGCl, 2021). The Alliance is the lead agency working with Botanic Gardens Conservation International $(\mathrm{BGCl})$, the University of Tasmania and RBGV. Along with the International Association of
Botanic Gardens, these organisations have provided direct funding and/or in-kind support. The Tool combines the strength of documented holdings of botanic gardens with species occurrences from GBIF and climatic inputs from WorldClim. About 17.7 million GBIF records have been linked to 48,481 distinct taxa, and 3,673 institutional gardens in the $\mathrm{BGCl}$ database have had their spatial location verified. The outcomes of the Tool are expected to include the following benefits: improved management of botanic gardens' living collections; reduced risk of long-term climate effects on long-lived species such as trees; more effective plant conservation through identification of climate-vulnerable species and suitable living collections for ex situ conservation; increased visibility and relevance of botanic gardens in urban greening; and new research opportunities in plant-climate science. The working prototype of the Tool (Fig. 12) was demonstrated through

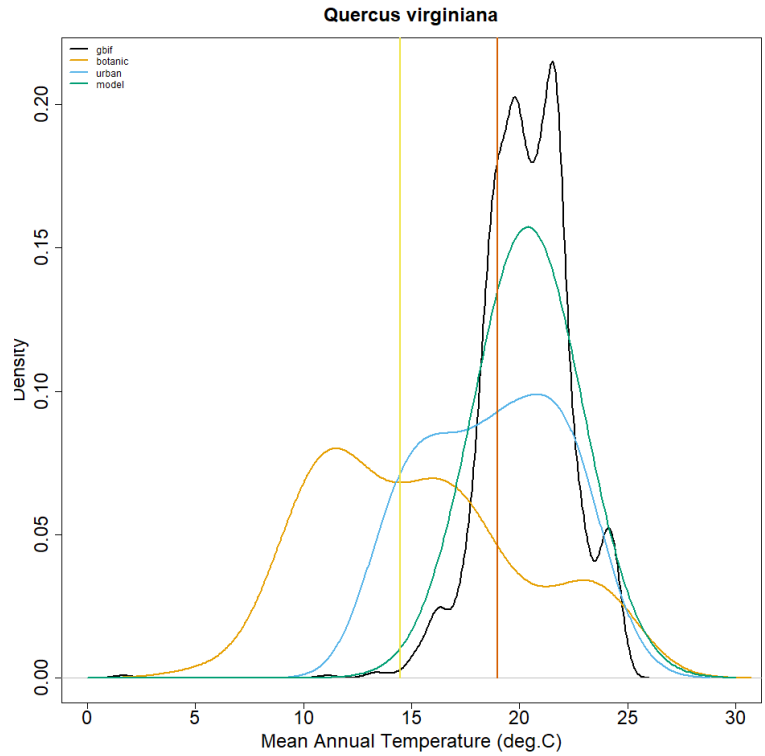

Fig. 12 An example of the preliminary results of the Global Climate Risk Assessment Tool prototype. The vertical lines represent Melbourne at mean annual temperatures of $14.5^{\circ} \mathrm{C}$ and $19{ }^{\circ} \mathrm{C}$. In this analysis, current occurrences of Quercus virginiana (southern live oak) are most frequent at temperatures of about $21^{\circ} \mathrm{C}$. This result may indicate that future warming in Melbourne will better suit its cultivation in the Gardens. Image: D Kendal. 
workshops to Alliance members in February 2021 and is expected to be available to members in late 2021.

\section{Membership of the Alliance}

Since its formation in December 2018, the Alliance has seen a rapid growth in membership. On 14 March 2021, there were 330 organisational and 71 associate members from 92 countries (Fig. 13). This progress builds on the Alliance principle: 'recruit for and celebrate diversity'. This overwhelming response in a relatively short time reflects the need for the Alliance and the desire for more capacity and collaboration on a global scale.

\section{Conclusion}

Climate change is a global problem that transcends the boundaries of individual arboreta and botanic gardens. Furthermore, plant distribution is often not constrained by political limits as natural habitats can extend across regions and countries (Enquist et al., 2016), and even further for those taxa held in the living collections of botanic gardens worldwide. When this enormous spatial scale is combined with the complexity and uncertainty of the future, it requires both a diversity of expertise and perspectives and the collaboration of many organisations to effectively respond to issues (Schulman \& Lehvävirta, 2011). No botanic garden can fully tackle these problems on its own, especially those that have fewer resources. Collaboration provides a powerful mechanism to pool resources, share skills and insights, and provide greater reach towards tackling climate change and mitigating its many potential outcomes. What the future holds

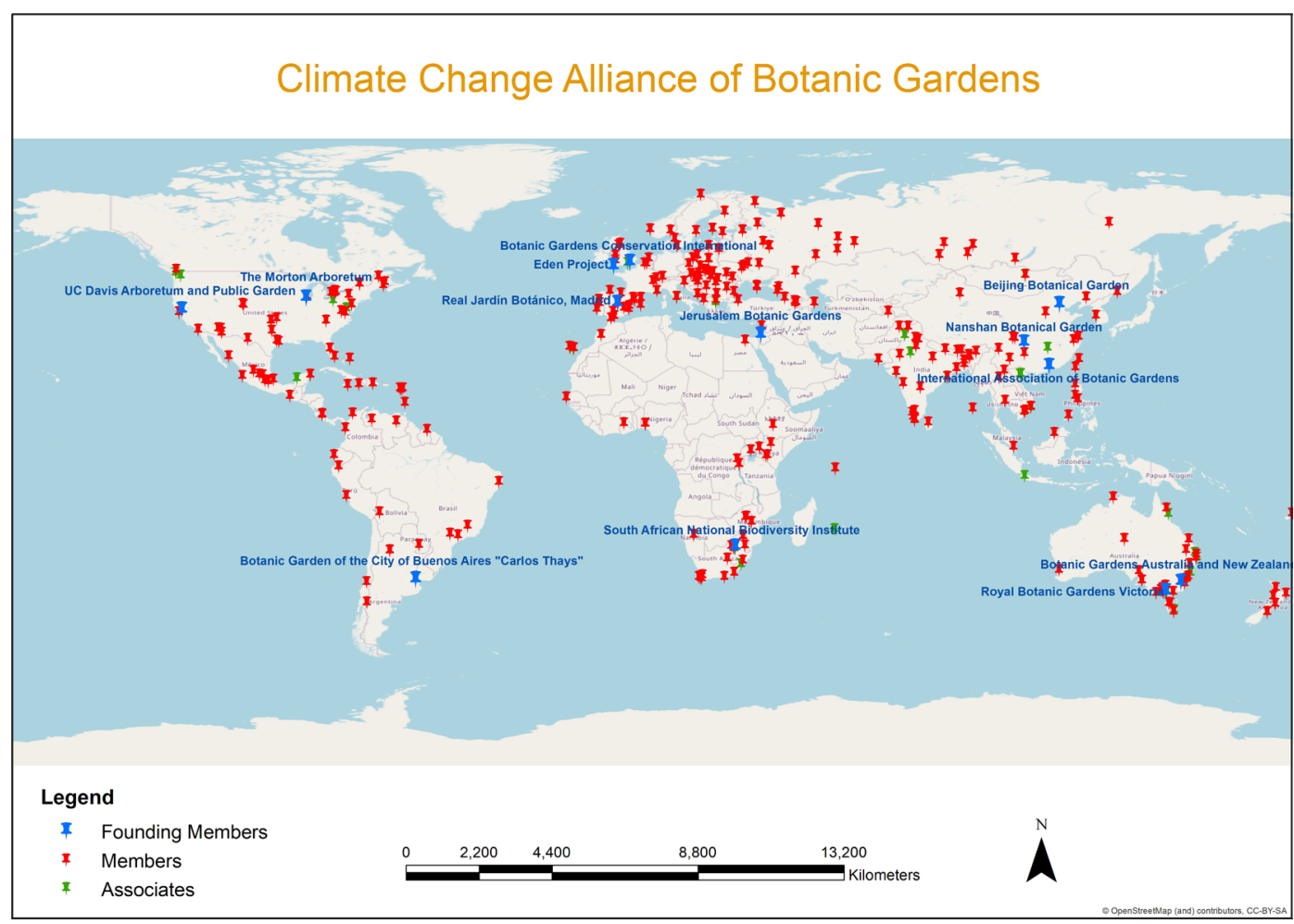

Fig. 13 Current spread of membership of the Climate Change Alliance of Botanic Gardens worldwide. The founding members are shown by blue pins and text. Map: P. Symes. 
is yet to be discovered, but many plants face unencountered climate risks: 'In the next 50 years, 20-50 per cent of current plant species in botanic gardens and urban landscapes will likely confront temperatures those species have never experienced before' (Dr D. Kendal, University of Tasmania, pers. comm.). In facing this climate change emergency, botanic gardens have the depth of proficiency and community of practice across the globe to meet these challenges (Manuti et al., 2017; Entwisle, 2019).

Learn more at https://www.rbg.vic.gov. au/initiatives/climate-change-alliance

\section{Acknowledgements}

We would like to thank Tessa Kum, Horticultural Support Officer, RBGV, and Alastair Robinson, Manager, Biodiversity Services, RBGV, who provided valuable feedback to improve this paper.

\section{References}

\section{AKBARI, H., CARTALIS, C., KOLOKOTSA, D., MUSCIO, A., PISELLO, A.L., ROSSI, F.,} SANTAMOURIS, M., SYNNEFA, A., WONG, N.H. \& ZINZI, M. (2016). Local climate change and urban heat island mitigation techniques - the state of the art. Journal of Civil Engineering and Management, 22(1): 1-16. doi: https://doi.org/10.3846/13923730. 2015.1111934

ATLAS OF LIVING AUSTRALIA (2021). Eucalyptus pauciflora: Benambra Snow-Gum. Available online: https://bie.ala.org.au/species/https://id.biodiversity. org.au/node/apni/2897845 (accessed March 2021).

\section{AUSTRALIAN BUREAU OF METEOROLOGY (2021a). Annual Climate Summary for Greater Melbourne. Available online: www.bom.gov. au/climate/current/annual/vic/archive/2020. melbourne.shtml (accessed March 2021).}

\section{AUSTRALIAN BUREAU OF METEOROLOGY} (2021b). Climate Data Online. Available online: www.bom.gov.au/climate/data/ (accessed March 2021).

\section{AUSTRALIAN NATIONAL BOTANIC GARDENS} (2021). Australian Flora Statistics. Australian National Botanic Gardens (ANBG). Available online: www.anbg.gov.au/cpbr/australian-plants/statistics. html (accessed March 2021).

BARNES, M.L., BODIN, Ö., GUERRERO, A.M., MCALLISTER, R.R.J., ALEXANDER, S.M. \& ROBINS, G. (2017). The social structural foundations of adaptation and transformation in social-ecological systems. Ecology and Society, 22(4): 16. doi: https:// doi.org/10.5751/ES-09769-220416

BARRETT, S. \& YATES, C.J. (2015). Risks to a mountain summit ecosystem with endemic biota in southwestern Australia. Austral Ecology, 40(4): 423-432. doi: https://doi.org/10.1111/aec.12199

BERTHON, K., ESPERON-RODRIGUEZ, M., BEAUMONT, L.J., CARNEGIE, A.J. \& LEISHMAN, M.R. (2018). Assessment and prioritisation of plant species at risk from myrtle rust (Austropuccinia psidii) under current and future climates in Australia. Biological Conservation, 218: 154-162. doi: https://doi.org/10.1016/j. biocon.2017.11.035

BODIN, Ö., ROBINS, G., MCALLISTER, R.R.J., GUERRERO, A.M., CRONA, B., TENGÖ, M. \& LUBELL, M. (2016). Theorizing benefits and constraints in collaborative environmental governance: a transdisciplinary social-ecological network approach for empirical investigations. Ecology and Society, 21(1): 40. doi: http://dx.doi. org/10.5751/ES-08368-210140

BООTH, T.H. (2017). Going nowhere fast: a review of seed dispersal in eucalypts. Australian Journal of Botany, 65(5): 401-410. doi: https://doi. org/10.1071/BT17019

BOOTH, T.H., NIX, H.A., BUSBY, J.R. \& HUTCHINSON, M.F. (2014). Bioclim: The first species distribution modelling package, its early applications and relevance to most current MaxEnt studies. Diversity and Distributions, 20(1): 1-9. doi: https://doi.org/10.1111/ddi.12144

BOTANIC GARDENS CONSERVATION INTERNATIONAL (2021). GlobalTreeSearch. Available online: https://tools.bgci.org/global_tree_ search.php (accessed February 2021).

BOWMAN, D.M.J.S., MURPHY, B.P., NEYLAND, D.L.J., WILLIAMSON, G.J. \& PRIOR, L.D. (2014). Abrupt fire regime change may cause landscape-wide loss of mature obligate seeder 
forests. Global Change Biology, 20(3): 1008-1015. doi: https://doi.org/10.1111/gcb.12433

BROOKHOUSE, M.T. \& BI, H. (2009). Elevationdependent climate sensitivity in Eucalyptus pauciflora Sieb. ex Spreng. Trees, 23: 1309-1320. doi: https://doi.org/10.1007/s00468-009-0372-6

BRUMMITT, R., PANDO, F., HOLLIS, S. \& BRUMMITT, N. (2001). World Geographical Scheme for Recording Plant Distributions. International Working Group on Taxonomic Databases for Plant Sciences (TDWG).

BURGESS, T.I., MCDOUGALL, K.L., SCOTT, P.M., HARDY, G.E.S. \& GARNAS, J. (2019). Predictors of Phytophthora diversity and community composition in natural areas across diverse Australian ecoregions. Ecography, 42: 565-577. doi: https://doi.org/10.1111/ecog.03904

BURLEY, H., BEAUMONT, L.J., OSSOLA, A., BAUMGARTNER, J.B., GALLAGHER, R., LAFFAN, S., ESPERON-RODRIGUEZ, M., MANEA, A. \& LEISHMAN, M.R. (2019). Substantial declines in urban tree habitat predicted under climate change. Science of The Total Environment, 685: 451-462. doi: https://doi.org/10.1016/j. scitotenv.2019.05.287

BUSH, A., CATULLO, R.A., MOKANY, K., THORNHILL, A.H., MILLER, J.T. \& FERRIER, S. (2018). Truncation of thermal tolerance niches among Australian plants. Global Ecology and Biogeography, 27(1): 22-31. doi: https://doi. org/10.1111/geb.12637

CAHILL, D.M., ROOKES, J.E., WILSON, B.A., GIBSON, L. \& MCDOUGALL, K.L. (2008). Phytophthora cinnamomi and Australia's biodiversity: impacts, predictions and progress towards control. Australian Journal of Botany, 56(4): 279-310. doi: https://doi.org/10.1071/BT07159

CAMAC, J.S., WILLIAMS, R.J., WAHREN, C.-H., HOFFMANN, A.A. \& VESK, P.A. (2017). Climatic warming strengthens a positive feedback between alpine shrubs and fire. Global Change Biology, 23(8): 3249-3258. doi: https://doi.org/10.1111/gcb.13614

CÁMARA-LERET, R., RAES, N., ROEHRDANZ, P., DE FRETES, Y., HEATUBUN, C., ROEBLE, L., SCHUITEMAN, A., VAN WELZEN, P. \& HANNAH,

L. (2019). Climate change threatens New Guinea's biocultural heritage. Science Advances, 5(11): eaaz1455. doi: https://doi.org/10.1126/sciadv. aaz1455
CARNEGIE, A.J., LIDBETTER, J.R., WALKER, J., HORWOOD, M.A., TESORIERO, L., GLEN, M. \& PRIEST, M.J. (2010). Uredo rangelii, a taxon in the guava rust complex, newly recorded on Myrtaceae in Australia. Australasian Plant Pathology, 39(5): 463-466. doi: https://doi.org/10.1071/AP10102

CARRUS, G., SCOPELLITI, M., PANNO, A., LAFORTEZZA, R., COLANGELO, G., PIRCHIO, S., FERRINI, F., SALBITANO, F., AGRIMI, M., PORTOGHESI, L., SEMENZATO, P. \& SANESI, G. (2017). A different way to stay in touch with 'urban nature': the perceived restorative qualities of botanical gardens. Frontiers in Psychology, 8: 914. doi: https://doi.org/10.3389/fpsyg.2017.00914

CAVENDER, N., SMITH, P. \& MARFLEET, K. (2019). BGCI Technical Review: the role of botanic gardens in urban greening and conserving urban biodiversity. Available online: https://www.bgci. org/wp/wp-content/uploads/2019/06/TechnicalReview-Urban-Greening.pdf (accessed September 2020).

CHEN, G. \& SUN, W. (2018). The role of botanical gardens in scientific research, conservation, and citizen science. Plant Diversity, 40(4): 181-188. doi: https://doi.org/10.1016/j.pld.2018.07.006

CHRISTMAS, M.J., BREED, M.F. \& LOWE, A.J. (2016). Constraints to and conservation implications for climate change adaptation in plants. Conservation Genetics, 17: 305-320. doi: https://doi.org/10.1007/s10592-015-0782-5

CLARKE, J.M., GROSE, M., THATCHER, M., ROUND, V. \& HEADY, C. (2019). Greater Melbourne Climate Projections 2019. CSIRO, Melbourne.

CORLETT, R.T. (2016). Plant diversity in a changing world: status, trends, and conservation needs. Plant Diversity, 38(1): 10-16. doi: https://doi. org/10.1016/j.pld.2016.01.001

COSTION, C.M., SIMPSON, L., PERT, P.L., CARLSEN, M.M., JOHN KRESS, W. \& CRAYN, D. (2015). Will tropical mountaintop plant species survive climate change? Identifying key knowledge gaps using species distribution modelling in Australia. Biological Conservation, 191: 322-330. doi: https://doi.org/10.1016/j. biocon.2015.07.022

CRIMMINS, S.M., DOBROWSKI, S.Z., GREENBERG, J.A., ABATZOGLOU, J.T. \& MYNSBERGE, A.R. (2011). Changes in climatic water balance drive downhill shifts in plant species' optimum 
elevations. Science, 331: 324-327. doi: https://doi. org/10.1126/science. 1199040

CSIRO (2008). Climate Change in Victoria. Department of Sustainability and Environment, The State of Victoria, Melbourne. Available online: www. climatechange.vic.gov.au (accessed May 2009).

CSIRO (2012). Climate and water availability in south-eastern Australia: a synthesis of findings from Phase 2 of the South Eastern Australian Climate Initiative (SEACI). doi: https://doi. org/10.4225/08/584af3986fe 96

CSIRO \& BOM (2020). State of the Climate 2020. Commonwealth of Australia. Available online: www.bom.gov.au/state-of-the-climate (accessed February 2021).

\section{DEPARTMENT OF HEALTH (2014). The}

Health Impacts of the January 2014 Heatwave in Victoria. Available online: www2.health.vic. gov.au/public-health/environmental-health/ climate-weather-and-public-health/heatwavesand-extreme-heat/heatwave-research (accessed March 2021).

DEWLP (2019). Growing Victoria's Botanic Gardens Grants Program. Available online: www. forestsandreserves.vic.gov.au/grants/growingvictorias-botanic-gardens-grants-program (accessed January 2020).

DICKSON, K., BARTEL, R., ROUX, D. \& ALTER, T.R. (2019). Achieving organisational learning in natural resource management. In: MARTIN, P., ALTER, T., HINE, D. \& HOWARD, T. (eds), Communitybased Control of Invasive Species. CSIRO Publishing, Clayton, pp. 48-73.

DIRNBÖCK, T., ESSL, F. \& RABITSCH, W. (2011). Disproportional risk for habitat loss of high-altitude endemic species under climate change. Global Change Biology, 17(2): 990-996. doi: https://doi. org/10.1111/j.1365-2486.2010.02266.x

DODD, J. \& JONES, C. (2010). Redefining the Role of Botanic Gardens: Towards a New Social Purpose. Research Centre for Museums and Galleries (RCMG), Leicester. Available online: www.bgci.org/files/ Worldwide/Education/Social_inclusion/social\%20 inclusion\%20report.pdf (accessed January 2020).

DUNN, C.P. (2017). Biological and cultural diversity in the context of botanic garden conservation strategies. Plant Diversity, 39(6): 396-401. doi: https://doi.org/10.1016/j.pld.2017.10.003
ELLISON, D., MORRIS, C.E., LOCATELLI, B., SHEIL, D., COHEN, J., MURDIYARSO, D., GUTIERREZ, V., NOORDWIJK, M.V., CREED, I.F., POKORNY, J., GAVEAU, D., SPRACKLEN, D.V. ET AL. (2017). Trees, forests and water: cool insights for a hot world. Global Environmental Change, 43: 51-61. doi: https://doi.org/10.1016/j. gloenvcha.2017.01.002

ENQUIST, B.J., CONDIT, R., PEET, R.K., SCHILDHAUER, M. \& THIERS, B.M. (2016). Cyberinfrastructure for an integrated botanical information network to investigate the ecological impacts of global climate change on plant biodiversity. PeerJ Preprints, 4: e2615v2. doi: https:// doi.org/10.7287/peerj.preprints.2615v2

ENTWISLE, T.J. (2019). R-E-S-P-E-C-T: how Royal Botanic Gardens Victoria is responding to climate change. Plants, People, Planet, 1(2): 77-83. doi: https://doi.org/10.1002/ppp3.18

FANT, J.B., HAVENS, K., KRAMER, A.T., WALSH, S.K., CALLICRATE, T., LACY, R.C., MAUNDER, M., MEYER, A.H. \& SMITH, P.P. (2016). What to do when we can't bank on seeds: what botanic gardens can learn from the zoo community about conserving plants in living collections. American Journal of Botany, 103(9): 1541-1543. doi: https:// doi.org/10.3732/ajb.1600247

FICK, S.E. \& HIJMANS, R.J. (2017). WorldClim 2: new 1-km spatial resolution climate surfaces for global land areas. International Journal of Climatology, 37(12): 4302-4315. doi: https://doi. org/10.1002/joc.5086

FILKOV, A.I., NGO, T., MATTHEWS, S., TELFER, S. \& PENMAN, T.D. (2020). Impact of Australia's catastrophic 2019/20 bushfire season on communities and environment. Retrospective analysis and current trends. Journal of Safety Science and Resilience, 1(1): 44-56. doi: https://doi. org/10.1016/j.jnlssr.2020.06.009

FORSTER, P.M., MAYCOCK, A.C., MCKENNA, C.M. \& SMITH, C.J. (2020). Latest climate models confirm need for urgent mitigation. Nature Climate Change, 10: 7-10. doi: https://doi.org/10.1038/ s41558-019-0660-0

FULLER, R.A., IRVINE, K.N., DEVINE-WRIGHT, P., WARREN, P.H. \& GASTON, K.J. (2007).

Psychological benefits of greenspace increase with biodiversity. Biology Letters, 3(4): 390-394. doi: https://doi.org/10.1098/rsbl.2007.0149 
GALLAGHER, R. (2020). National prioritisation of Australian plants affected by the 2019-2020 bushfire season. Report to the Commonwealth Department of Agriculture, Water and Environment. Available online: https://www.environment.gov.au/system/files/ pages/289205b6-83c5-480c-9a7d-3fdf3cde2f68/ files/final-national-prioritisation-australian-plantsaffected-2019-2020-bushfire-season.pdf (accessed March 2021).

GALLAGHER, R.V., ALLEN, S. \& WRIGHT, I.J. (2019). Safety margins and adaptive capacity of vegetation to climate change. Scientific Reports, 9: 8241. doi: https://doi.org/10.1038/ s41598-019-44483-x

GBIF.ORG (2021). Plantae. Available online: www. gbif.org/species/6/metrics (accessed March 2021).

GEOSCIENCE AUSTRALIA (2021). Elevations.

Available online: https://www.ga.gov.au/ scientific-topics/national-location-information/ landforms/elevations\#: :text=Australia\%20is\%20 the $\% 20$ lowest $\% 20$ continent, $2228 \% 20$ metres $\% 20$ above\%20sea\%20level (accessed March 2021).

GODFREE, R.C., KNERR, N., ENCINAS-VISO, F., ALBRECHT, D., BUSH, D., CARGILL, D.C., CLEMENTS, M., GUEIDAN, C., GUJA, L.K., HARWOOD, T., JOSEPH, L., LEPSCHI, B., NARGAR, K., SCHMIDT-LEBUHN, A. \& BROADHURST, L.M. (2021). Implications of the 2019-2020 megafires for the biogeography and conservation of Australian vegetation. Nature Communications, 12(1): 1023. doi: https://doi.org/10.1038/ s41467-021-21266-5

GONZALES-IWANCIW, J., DEWULF, A. \& KARLSSON-VINKHUYZEN, S. (2019). Learning in multi-level governance of adaptation to climate change - a literature review. Journal of Environmental Planning and Management, 63(5): 779-797. doi: https://doi.org/10.1080/09640568.20 19.1594725

GRATZFELD, J. (2017). What is conservation horticulture? BGjournal, 14(2): 14-17. Available online: www.bgci.org/wp/wp-content/ uploads/2019/04/BGjournal\%2014_2.pdf (accessed January 2021).

GRIFFITH, M.P., CLASE, T., TORIBIO, P., PIÑEYRO, Y.E., JIMENEZ, F., GRATACOS, X., SANCHEZ, V., MEEROW, A., MEYER, A., KRAMER, A., FANT, J., HAVENS, K., MAGELLAN, T.M., DOSMANN,
M. \& HOBAN, S. (2020). Can a botanic garden metacollection better conserve wild plant diversity? A case study comparing pooled collections with an ideal sampling model. International Journal of Plant Sciences, 181(5): 485-496. doi: https://doi.org/10.1086/707729

GROSE, M., ABBS, D., BHEND, J., CHIEW, F., CHURCH, J., EKSTRÖM, M., KIRONO, D., ANDREW, L., LUCAS, C., MCINNES, K., MOISE, A., MONSELESAN, D. ET AL. (2015). Southern Slopes Cluster Report, Climate Change in Australia Projections for Australia's Natural Resource Management Regions. Cluster Reports, EKSTRÖM, M. ET AL. (eds). CSIRO and Bureau of Meteorology, Australia. Available online: www.ppwrcs.vic.gov.au/ wp-content/uploads/sites/5/2018/12/SOUTHERN_ SLOPES_CLUSTER_REPORT_1.pdf (accessed January 2021).

GROSE, M.R., NARSEY, S., DELAGE, F.P., DOWDY, A.J., BADOR, M., BOSCHAT, G., CHUNG, C., KAJTAR, J.B., RAUNIYAR, S., FREUND, M.B., LYU, K., RASHID, H. ET AL. (2020). Insights from CMIP6 for Australia's future climate. Earth's Future, 8(5): e2019EF001469. doi: https://doi. org/10.1029/2019EF001469

HAASE, D., LARONDELLE, N., ANDERSSON, E., ARTMANN, M., BORGSTRÖM, S., BREUSTE, J., GOMEZ-BAGGETHUN, E., GREN, Å., HAMSTEAD, Z., HANSEN, R., KABISCH, N., KREMER, P. ET AL. (2014). A quantitative review of urban ecosystem service assessments: concepts, models, and implementation. AMBIO, 43: 413-433. doi: https:// doi.org/10.1007/s13280-014-0504-0

HARRIS, R.M.B., BEAUMONT, L.J., VANCE, T.R., TOZER, C.R., REMENYI, T.A., PERKINSKIRKPATRICK, S.E., MITCHELL, P.J., NICOTRA, A.B., MCGREGOR, S., ANDREW, N.R., LETNIC, M., KEARNEY, M.R. ET AL. (2018). Biological responses to the press and pulse of climate trends and extreme events. Nature Climate Change, 8: 579-587. doi: https://doi.org/10.1038/s41558-018-0187-9

HARSCH, M.A., HULME, P.E., MCGLONE, M.S. \& DUNCAN, R.P. (2009). Are treelines advancing? A global meta-analysis of treeline response to climate warming. Ecology Letters, 12(10): 1040-1049. doi: https://doi. org/10.1111/j.1461-0248.2009.01355.x

HAUSFATHER, Z. \& PETERS, G.P. (2020). Emissions - the 'business as usual' story is misleading. 
Nature, 577, 618-620. doi: https://doi.org/10.1038/ d41586-020-00177-3

HIJMANS, R., CAMERON, S., PARRA, J., JONES, P. \& JARVIS, A. (2005). WorldClim - Very High Resolution Interpolated Climate Surfaces for Global Land Areas. Version 1.4 (release 3). Museum of Vertebrate Zoology, University of California, Berkeley, CA. Available online: www.worldclim.org (accessed March 2019).

HOFFMANN, A.A., RYMER, P.D., BYRNE, M., RUTHROF, K.X., WHINAM, J., MCGEOCH, M., BERGSTROM, D.M., GUERIN, G.R., SPARROW, B., JOSEPH, L., HILL, S.J., ANDREW, N.R. ET $A L$. (2019). Impacts of recent climate change on terrestrial flora and fauna: some emerging Australian examples. Austral Ecology, 44(1): 3-27. doi: https://doi.org/10.1111/aec.12674

HUANG, K., LI, X., LIU, X. \& SETO, K.C. (2019). Projecting global urban land expansion and heat island intensification through 2050. Environmental Research Letters, 14(11): 114037. doi: https://doi. org/10.1088/1748-9326/ab4b71

HUGHES, L. (2011). Climate change and Australia: key vulnerable regions. Regional Environmental Change, 11: 189-195. doi: https://doi.org/10.1007/ s10113-010-0158-9

HUNJAN, M.S. \& LORE, J.S. (2020). Climate change: impact on plant pathogens, diseases, and their management. In: JABRAN, K., FLORENTINE, S. \& CHAUHAN, B. (eds), Crop Protection Under Changing Climate. Springer International Publishing, Cham. doi: 10.1007/978-3-030-46111-9

\section{INTERGOVERNMENTAL PANEL ON CLIMATE} CHANGE (2014). Climate Change 2014: Synthesis Report. Contribution of Working Groups I, II and III to the Fifth Assessment Report of the Intergovernmental Panel on Climate Change. CORE WRITING TEAM, PACHAURI, R.K. \& MEYER, L.A. (eds), IPCC, Geneva.

\section{INTERGOVERNMENTAL PANEL ON CLIMATE}

CHANGE (2018). Summary for Policymakers. In: MASSON-DELMOTTE, V., ZHAI, P., PÖRTNER, H.-O., ROBERTS, D., SKEA, J., SHUKLA, P.R., PIRANI, A., MOUFOUMA-OKIA, W., PÉAN, C., PIDCOCK, R., CONNORS, S., MATTHEWS, J.B.R., CHEN, Y. ET AL. (eds), Global warming of $1.5^{\circ} \mathrm{C}$. An IPCC Special Report on the impacts of global warming of $1.5^{\circ} \mathrm{C}$ above pre-industrial levels and related global greenhouse gas emission pathways, in the context of strengthening the global response to the threat of climate change, sustainable development, and efforts to eradicate poverty. World Meteorological Organization, Geneva.

JONES, M.W., SMITH, A., BETTS, R., CANADELL, J.G., PRENTICE, I.C. \& LE QUÉRÉ, C. (2020). Climate change increases risk of wildfires. Available online: https://sciencebrief.org/briefs/wildfires (accessed March 2021).

KARL, F. (2012). A free energy principle for biological systems. Entropy, 14(11): 2100-2121. doi: https://doi.org/10.3390/e14112100

KENDAL, D. (2017). Climate risk assessment of potential threatened species for the living plant collections in the Melbourne Gardens, Royal Botanic Gardens Victoria. Internal report. Burnley Campus, School of Ecosystem and Forest Sciences, University of Melbourne \& Clean Air and Urban Landscape hub of the National Environmental Science programme \& School of Technology, Environments and Design, University of Tasmania.

KENDAL, D., DOBBS, C., GALLAGHER, R.V., BEAUMONT, L.J., BAUMANN, J., WILLIAMS, N.S.G. \& LIVESLEY, S.J. (2018). A global comparison of the climatic niches of urban and native tree populations. Global Ecology and Biogeography, 27(5): 629-637. doi: https://doi.org/10.1111/ geb.12728

KENDAL, D. \& FARRAR, A. (2017). Assessment of the climate change risk to the living plant collections in the Melbourne Gardens, Royal Botanic Gardens Victoria. Internal report.

LENOIR, J., GÉGOUT, J.-C., GUISAN, A., VITTOZ, P., WOHLGEMUTH, T., ZIMMERMANN, N.E., DULLINGER, S., PAULI, H., WILLNER, W. \& SVENNING, J.-C. (2010). Going against the flow: potential mechanisms for unexpected downslope range shifts in a warming climate. Ecography, 33(2): 295-303. doi: https://doi. org/10.1111/j.1600-0587.2010.06279.x

LIVESLEY, S.J., MCPHERSON, G.M. \& CALFAPIETRA, C. (2016). The urban forest and ecosystem services: impacts on urban water, heat, and pollution cycles at the tree, street, and city scale. Journal of Environmental Quality, 45(1): 119-124. doi: https://doi.org/10.2134/ jeq2015.11.0567

MACKEY, B., GOULD, S., LINDENMAYER, D., NORMAN, P. \& TAYLOR, C. (2021). How does 
climate affect bushfire risks in the native forests of south-eastern Australia? Bushfire Recovery Project Report No.1. Griffith University and The Australian National University. Available online: https://www. preventionweb.net/go/75115 (accessed March 2021).

MAKINSON, R. (2018). Myrtle Rust reviewed: the impacts of the invasive pathogen Austropuccinia psidii on the Australian environment. Plant Biosecurity Cooperative Research Centre, Canberra. Available online: http://www.apbsf.org.au/ wp-content/uploads/2018/11/Myrtle-Rust-reviewedJune-22-2018-web.pdf (accessed January 2021).

MAKINSON, R.O., PEGG, G.S. \& CARNEGIE, A.J. (2020). Myrtle Rust in Australia - a National Action Plan. Australian Plant Biosecurity Science Foundation, Canberra. Available online: https:// www.anpc.asn.au/wp-content/uploads/2020/11/ Myrtle-Rust-National-Action-Plan-2020.pdf (accessed January 2021).

MANUTI, A., IMPEDOVO, M.A. \& DE PALMA, P.D. (2017). Managing social and human capital in organizations: communities of practices as strategic tools for individual and organizational development. Journal of Workplace Learning, 29(3): 217-234. doi: https://doi.org/10.1108/ JWL-07-2016-0062

MARSELLE, M.R., STADLER, J., KORN, H., IRVINE, K.N. \& BONN, A. (2019). Biodiversity and health in the face of climate change: perspectives for science, policy and practice. In: MARSELLE, M.R., STADLER, J., KORN, H., IRVINE, K.N. \& BONN, A. (eds), Biodiversity and Health in the Face of Climate Change. Springer International Publishing, Cham.

MARTÍN, M.P., BARREIRO, G., DUQUE, A.M., MAGALHÃES, Z. \& MANRIQUE, E. (2020).

Botanical gardens facing biodiversity conservation and climate change. In: LEAL FILHO, W., AZUL, A.M. BRANDLI, L., LANGE SALVIA, A. \& WALL, T. (eds), Life on Land. Springer International Publishing, Cham.

MARTÍN-LÓPEZ, B., PALOMO, I., GARCÍALLORENTE, M., INIESTA-ARANDIA, I., CASTRO, A.J., GARCÍA DEL AMO, D., GÓMEZ-BAGGETHUN, E. \& MONTES, C.

(2017). Delineating boundaries of socialecological systems for landscape planning: a comprehensive spatial approach. Land Use Policy, 66(4): 90-104. doi: http://dx.doi.org/10.1016/j. landusepol.2017.04.040
MOUNCE, R., SMITH, P. \& BROCKINGTON, S. (2017). Ex situ conservation of plant diversity in the world's botanic gardens. Nature Plants, 3: 795-802. doi: https://doi.org/10.1038/ s41477-017-0019-3

NACCARELLA, A., MORGAN, J.W., CUTLER, S.C. \& VENN, S.E. (2020). Alpine treeline ecotone stasis in the face of recent climate change and disturbance by fire. PloS ONE, 15(4): e0231339. doi: 10.1371/ journal.pone.0231339

NAROUEI-KHANDAN, H.A., WORNER, S.P., VILJANEN, S.L.H., VAN BRUGGEN, A.H.C. \& JONES, E.E. (2020). Projecting the suitability of global and local habitats for myrtle rust (Austropuccinia psidii) using model consensus. Plant Pathology, 69(1): 17-27. doi: https://doi.org/10.1111/ppa.13111

NEGRU, T. (2018). Self-organization, autopoiesis, free-energy principle and autonomy. Organon F, 25: 215-243.

NIC LUGHADHA, E., BACHMAN, S.P., LEÃO, T.C.C., FOREST, F., HALLEY, J.M., MOAT, J., ACEDO, C., BACON, K.L., BREWER, R.F.A., GÂTEBLÉ, G., GONÇALVES, S.C., GOVAERTS, R. ET AL. (2020). Extinction risk and threats to plants and fungi. Plants, People, Planet, 2(5): 389-408. doi: https://doi. org/10.1002/ppp3.10146

OPDAM, P., LUQUE, S., NASSAUER, J., VERBURG, P.H. \& WU, J. (2018). How can landscape ecology contribute to sustainability science? Landscape Ecology, 33: 1-7. doi: https://doi.org/10.1007/ s10980-018-0610-7

O'SULLIVAN, K.S.W., RUIZ-BENITO, P., CHEN, J.-C. \& JUMP, A.S. (2021). Onward but not always upward: individualistic elevational shifts of tree species in subtropical montane forests. Ecography, 44(1): 112-123. doi: https://doi.org/10.1111/ecog.05334

PAUTASSO, M., DÖRING, T.F., GARBELOTTO, M., PELLIS, L. \& JEGER, M.J. (2012). Impacts of climate change on plant diseases - opinions and trends. European Journal of Plant Pathology, 133: 295-313. doi: https://doi.org/10.1007/ s10658-012-9936-1

PEARSON, R.G. \& DAWSON, T.P. (2003). Predicting the impacts of climate change on the distribution of species: are bioclimate envelope models useful? Global Ecology and Biogeography, 12(5): 361-371. doi: https://doi. org/10.1046/j.1466-822X.2003.00042.x 
PEGG, G., CARNEGIE, A., GIBLIN, F. \& PERRY, S. (2018). Managing Myrtle Rust in Australia. Plant Biosecurity Cooperative Research Centre, Canberra.

PETERS, G.P., ANDREW, R.M., BODEN, T., CANADELL, J.G., CIAIS, P., LE QUÉRÉ, C., MARLAND, G., RAUPACH, M.R. \& WILSON, C. (2013). The challenge to keep global warming below $2{ }^{\circ} \mathrm{C}$. Nature Climate Change, 3: 4-6. doi: https://doi.org/10.1038/nclimate1783

PIMM, S.L. \& RAVEN, P.H. (2017). The fate of the world's plants. Trends in Ecology \& Evolution, 32(5): 317-320. doi: https://doi.org/10.1016/j. tree.2017.02.014

PRACH, K. \& WALKER, L.R. (2019). Differences between primary and secondary plant succession among biomes of the world. Journal of Ecology, 107(2): 510-516. doi: https://doi. org/10.1111/1365-2745.13078

PRIMACK, R.B. \& MILLER-RUSHING, A.J. (2009). The role of botanical gardens in climate change research: Tansley review. New Phytologist, 182(2): 303-313. doi: https://doi. org/10.1111/j.1469-8137.2009.02800.x

RAE, D. (2013). Botanic garden horticulturists - a threatened species? Sibbaldia, 11: 5-13. doi: https://doi.org/10.24823/Sibbaldia.2013.47

READ, R. \& O'RIORDAN, T. (2017). The precautionary principle under fire. Environment: Science and Policy for Sustainable Development, 59(5): 4-15. doi: https://doi.org/10.1080/00139157. 2017.1350005

\section{REAL JARDÍN BOTÁNICO DE MADRID (2020).} Ibero-American Node of Botanical Gardens against Climate Change (NIJAB-CC). Available online: http://www.rjb.csic.es/jardinbotanico/jardin/ contenido.php?Pag $=106 \&$ tipo $=$ noticia\&cod $=7665 \&$ fbclid=IwAROf2jLx32-7RTd1vQGiDBZcNv9HqXIAirfSW1Dg41b-6ieTQgiuS3MFyo (accessed February 2021).

ROHLI, R.V., JOYNER, T.A., REYNOLDS, S.J., SHAW, C. \& VÁZQUEZ, J.R. (2015). Globally Extended Köppen-Geiger climate classification and temporal shifts in terrestrial climatic types. Physical Geography, 36(2): 142-157. doi: https://doi.org/10.1 080/02723646.2015.1016382

ROYAL BOTANIC GARDENS VICTORIA (2016). Landscape Succession Strategy - Melbourne Gardens 2016-2036. Available online: https://www.rbg.vic. gov.au/initiatives/landscape-succession-strategy/ (accessed June 2016).

ROYAL BOTANIC GARDENS VICTORIA (2021a). Climate Change Alliance of Botanic Gardens. Available online: https://www.rbg.vic.gov.au/ initiatives/climate-change-alliance/ (accessed March 2021).

ROYAL BOTANIC GARDENS VICTORIA (2021b). Living Collections Database. Internal database.

RUTHROF, K.X., BRESHEARS, D.D., FONTAINE, J.B., FROEND, R.H., MATUSICK, G., KALA, J., MILLER, B.P., MITCHELL, P.J., WILSON, S.K., VAN KEULEN, M., ENRIGHT, N.J., LAW, D.J. ET $A L$. (2018). Subcontinental heat wave triggers terrestrial and marine, multi-taxa responses. Scientific Reports, 8: 13094. doi: https://doi. org/10.1038/s41598-018-31236-5

SAX, D.F., EARLY, R. \& BELLEMARE, J. (2013). Niche syndromes, species extinction risks, and management under climate change. Trends in Ecology \& Evolution, 28(9): 517-523. doi: https://doi. org/10.1016/j.tree.2013.05.010

SCHULMAN, L. \& LEHVÄVIRTA, S. (2011). Botanic gardens in the age of climate change. Biodiversity and Conservation, 20(2): 217-220. doi: https://doi. org/10.1007/s10531-010-9979-6

SCHWALM, C.R., GLENDON, S. \& DUFFY, P.B. (2020). RCP8.5 tracks cumulative $\mathrm{CO}_{2}$ emissions. Proceedings of the National Academy of Sciences, 117(46): 19656-19657. doi: https://doi.org/10.1073/ pnas. 2007117117

SELLMANN, D. \& BOGNER, F.X. (2013). Climate change education: quantitatively assessing the impact of a botanical garden as an informal learning environment. Environmental Education Research, 19(4): 415-429. doi: https://doi.org/10.10 80/13504622.2012.700696

SENTINELLA, A.T., WARTON, D.I., SHERWIN, W.B., OFFORD, C.A. \& MOLES, A.T. (2020). Tropical plants do not have narrower temperature tolerances, but are more at risk from warming because they are close to their upper thermal limits. Global Ecology and Biogeography, 29(8): 1387-1398. doi: https://doi.org/10.1111/ geb.13117

SHANAHAN, D.F., FULLER, R.A., BUSH, R., LIN, B.B. \& GASTON, K.J. (2015). The health benefits of urban nature: how much do we need? BioScience, 
65(5): 476-485. doi: https://doi.org/10.1093/biosci/ biv032

SOMMERVILLE, K.D., CUNEO, P., ERRINGTON, G., MAKINSON, R.O., PEDERSON, S., PHILLIPS, G., ROLLASON, A., VILER, V. \& OFFORD, C.A. (2020). Conservation in the wake of myrtle rust - a case study on two critically endangered Australian rainforest plants. Pacific Conservation Biology, 26(3): 218-229. doi: https://doi.org/10.1071/PC19026

STEENBERG, J.W., MILLWARD, A.A., NOWAK, D.J., ROBINSON, P.J. \& SMITH, S.M. (2019).

A social-ecological analysis of urban tree vulnerability for publicly-owned trees in a residential neighborhood. Arboriculture and Urban Forestry, 45(1): 9-23. doi: https://doi.org/10.48044/ jauf.2019.002

SUMANARATHNA, N., DUODU, B. \& ROWLINSON, S. (2020). Social capital, exploratory learning and exploitative learning in project-based firms: the mediating effect of collaborative environment. The Learning Organization, 27(4): 351-364. doi: https:// doi.org/10.1108/TLO-03-2020-0033

SYMES, P. (2017). Guiding landscape transition for climatic change: planning in the Royal Botanic Gardens Victoria, Australia. Acta Horticulturae, 1189: 137-142. doi: https://doi.org/10.17660/ ActaHortic.2017.1189.27

SYMES, P. \& CONNELLAN, G. (2013). Water management strategies for urban trees in dry environments: lessons for the future. Arboriculture \& Urban Forestry, 39(3): 116-124.

THIERS, B. (2021). National Herbarium of Victoria Collections Summary. Index Herbariorum. New York Botanical Garden's Virtual Herbarium. Available online: http://sweetgum.nybg.org/science/ih/ herbarium-details/?irn=125813 (accessed March 2021).

VINCENT, H., BORNAND, C.N., KEMPEL, A. \& FISCHER, M. (2020). Rare species perform worse than widespread species under changed climate. Biological Conservation, 246: 108586. doi: https:// doi.org/10.1016/j.biocon.2020.108586

WALKER, B. (2019). Finding Resilience: Change and Uncertainty in Nature and Society, CSIRO Publishing, Clayton.

WARREN, R., PRICE, J., GRAHAM, E., FORSTENHAEUSLER, N. \& VANDERWAL, J. (2018). The projected effect on insects, vertebrates, and plants of limiting global warming to $1.5^{\circ} \mathrm{C}$ rather than $2^{\circ} \mathrm{C}$. Science, 360(6390): 791-795. doi: https:// doi.org/10.1126/science.aar3646

WEBB, H. (2014). Carbon storage and accumulation in the Royal Botanic Gardens Melbourne tree population. Unpublished Masters thesis, University of Melbourne.

WEBB, L.B. \& HENNESSY, K. (2015). Projections for Selected Australian Cities. CSIRO and Bureau of Meteorology, Australia. doi: https://doi. org/10.5072/83/5849a23bc653f

WEHI, P.M., BEGGS, J.R. \& MCALLISTER, T.G. (2019). Ka mua, ka muri. New Zealand Journal of Ecology, 43(3): 1-8. doi: https://doi.org/10.20417/ nzjecol.43.40

WESTWOOD, M., CAVENDER, N., MEYER, A. \& SMITH, P. (2021). Botanic garden solutions to the plant extinction crisis. Plants, People, Planet, 3(1): 22-32. doi: https://doi.org/10.1002/ppp3.10134

ZARI, M.P. (2018). Regenerative Urban Design and Ecosystem Biomimicry. Routledge, Abingdon. 
